\title{
HYDROLOGIC CHARACTERISTICS OF SUMMER STREAM TEMPERATURES IN LITTLE CREEK AND SCOTTS CREEK AT THE SWANTON PACIFIC RANCH
}

\author{
A Thesis \\ presented to \\ the Faculty of California Polytechnic State University, \\ San Luis Obispo
}

\author{
In Partial Fulfillment \\ of the Requirements for the Degree \\ Master of Science in Forestry Sciences
}

by

Justin M. Louen

August 2016 
(C) 2016

Justin M. Louen

ALL RIGHTS RESERVED 


\section{COMMITTEE MEMBERSHIP}

TITLE:

AUTHOR:

DATE SUBMITTED:

DATE SUBMITTED:

.

Hydrologic Characteristics of Summer Stream Temperatures in Little Creek and Scotts Creek at the Swanton Pacific Ranch

Justin M. Louen

August 2016

COMMITTEE CHAIR: $\quad$ Christopher G. Surfleet, Ph.D., P.H.

Associate Professor of Hydrology and Watershed Management

COMMITTEE MEMBER: Brian C. Dietterick, Ph.D., P.H.

Director Swanton Pacific Ranch, Professor of Hydrology and Watershed Management

COMMITTEE MEMBER: Samantha J. Gill, Ph.D., RPF

Professor of Forest Biometrics and Management 


\begin{abstract}
Hydrologic Characteristics of Summer Stream Temperatures in Little Creek and Scotts Creek at the Swanton Pacific Ranch
\end{abstract}

Justin M. Louen

\begin{abstract}
Stream temperature impacts have resulted in increased restrictions on land management such as timber harvest and have created considerable uncertainty for future planning and management of redwood forestlands. Challenges remain in the assessment of downstream cumulative effects given the complexity of stream temperature dynamics. The goal of this research is to identify the risk of downstream temperature heating based on the summer low flow residence times, stream morphological characteristics, stream water storage, and heat budget exchanges. Stream temperature, hydrologic, climatic, and channel morphological data were collected on two, approximately $800 \mathrm{~m}$ stream reaches on Little Creek and Scotts Creek located in mixed coast redwood and Douglas-fir forests of Santa Cruz County, California. Spatially and temporally explicit stream temperature measurements were collected using distributed temperature sensing. A fluorescent dye tracer was used to gather information on summer streamflow including the quantification of residence time and hyporheic exchange. A heat budget approach was used to quantify individual heat flux components and to examine the processes of stream heating and cooling. Comparisons of observed and modeled temperatures between the two sites and the relative influences of individual heat budget components indicated that the magnitude and spatial frequency of subsurface-surface water interactions, along with incoming net radiation, played a substantial role in how heat was transferred through each system. Solar radiation exposure from stream shading and modeled groundwater inflows were important explanatory variables in the magnitude and spatial distribution of stream temperatures for the two streams located in the same watershed subjected to similar meteorological conditions. The measurement and evaluation of a stream's hydrologic characteristics, stream shading, and aspect ratio were statistically significant measurements $(\alpha<.05)$ associated with downstream temperature change for Little Creek. Only weak statistical relationships were found for Scotts Creek. Weak relationships may have been attributed to very low streamflow due to drought conditions creating longer water residence times on Scotts Creek. Heat budget modelling results indicated temperature increases in both study sites downstream of the hypothetical riparian canopy removal. The increases in stream temperature decreased with increased downstream distance from the canopy removal due to increased stream shading and advective cooling from hyporheic water exchanges. Potential increases in groundwater inflows following hypothetical canopy reduction scenarios reduced the effect of downstream temperature increases with greater reductions in stream temperature cooling with increased groundwater inputs.
\end{abstract}




\section{ACKNOWLEDGMENTS}

I would like to thank my project advisor, Dr. Chris Surfleet, for his assistance and support throughout my graduate studies and career endeavors. Thank you to Dr. Samantha Gill for our collaborations throughout the project. Special thanks to Dr. Brian Dietterick for his support with the project and professional guidance during my time spent at the Swanton Pacific Ranch. Finally, I would like to thank my family and friends for their love and support. Funding for this project has been made available by the California State University Agricultural Research Initiative (ARI) and the United States Department of Agriculture McIntire-Stennis Forestry Research Grant. DTS equipment and support has been provided by the Center for Transformative Environmental Monitoring Programs (CTEMPs) at the University of Nevada, Reno. Access to the Scotts Creek study site was granted by Big Creek Lumber Co. 


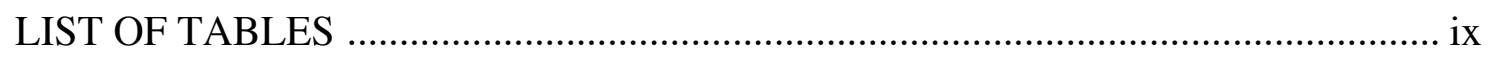

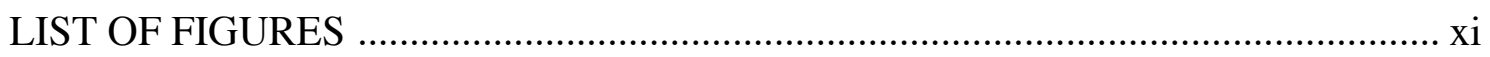

\section{CHAPTER}

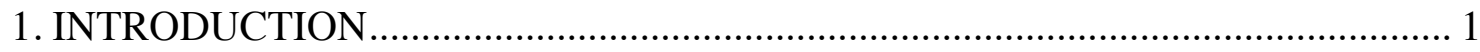

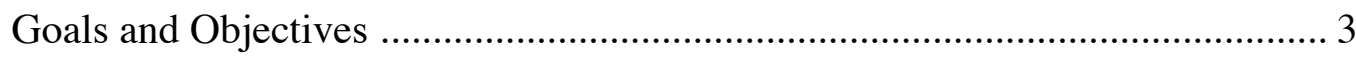

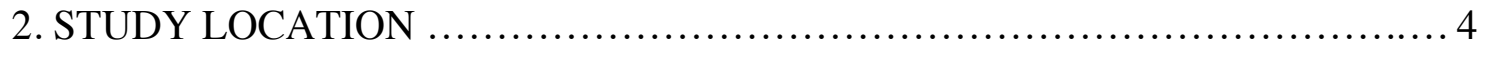

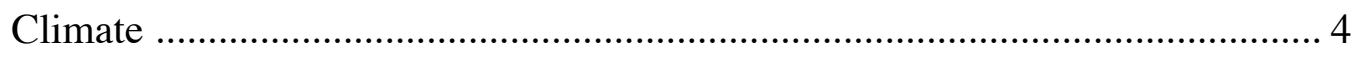

Geology and Geomorphology ......................................... 6

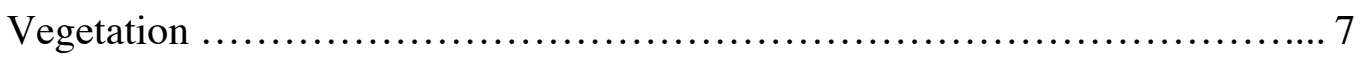

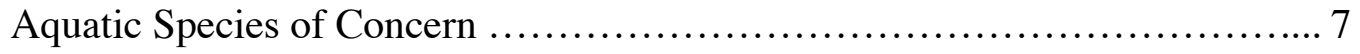

3. LITERATURE REVIEW ................................................. 9

Riparian Management Effects on Stream Temperature ......................... 9

Downstream Heat Transfer and Cooling Mechanisms ......................... 13

Stream Temperature Measurement Development ............................ 15

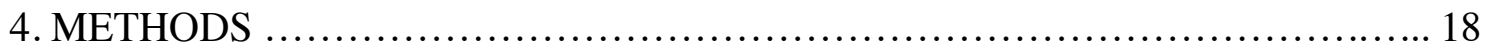

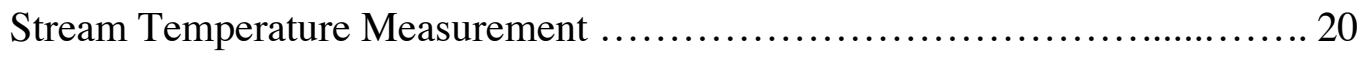

Little Creek Study Site ......................................... 20

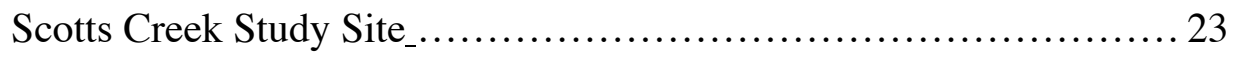

Streamflow and Hydrologic Processes ...................................... 24 
Climate Measurements

Little Creek Study Site ......................................... 27

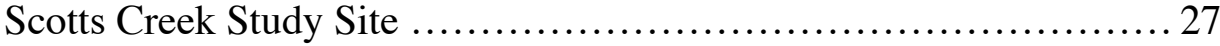

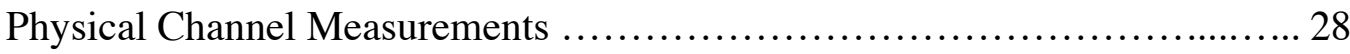

Heat Budget Model ....................................................... 29

Little Creek Study Site .......................................... 29

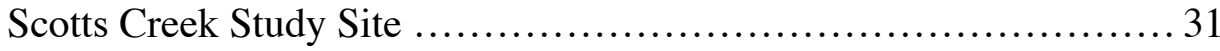

Statistical Analysis and Modelling Downstream Effects .................... 32

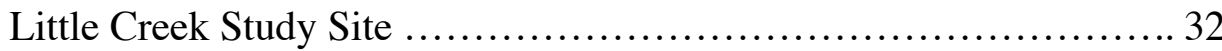

Scotts Creek Study Site ......................................... 35

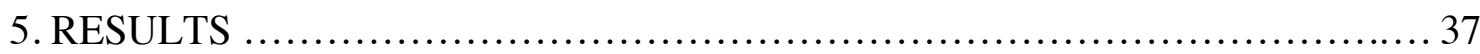

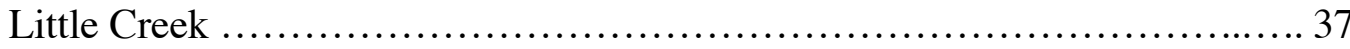

Hydrologic Processes .................................................. 39

Heat Budget Modeling .......................................... 41

Physical Characteristics and Daily Maximum Temperatures ........... 48

Modeled Effects from Shade Reduction ............................ 49

Modeled Effects from Groundwater Inflows ...................... 50

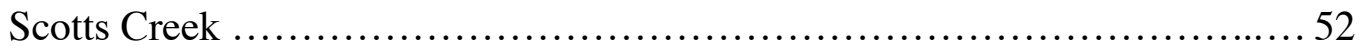

Hydrologic Processes ........................................... 53

Heat Budget Modeling .......................................... 54

Physical Characteristics and Daily Maximum Temperatures ............ 61

Modeled Effects from Shade Reduction .......................... 62 


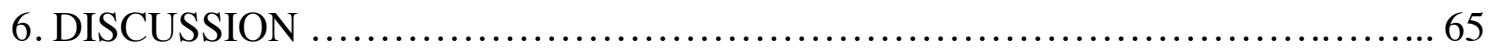

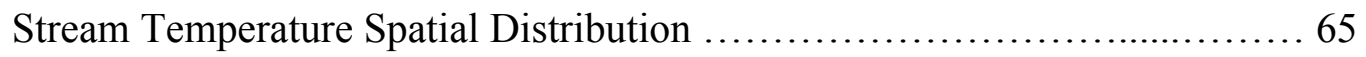

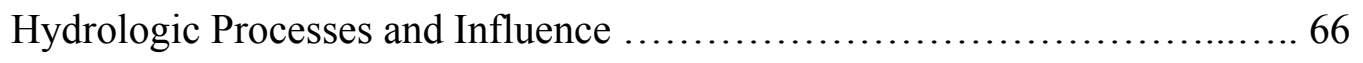

Proposed Methodologies for Predicting Downstream Effects ................... 69

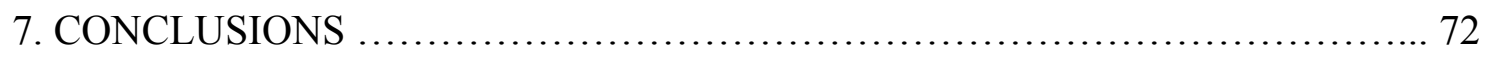

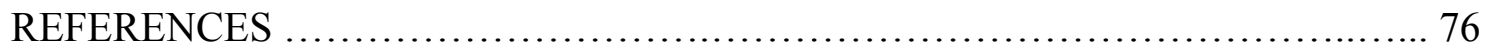




\section{LIST OF TABLES}

Table

Page

Table 1. DTS post-processing calibration statistics in deg. C

Table 2. Dye tracer measurement parameters for Little Creek and Scotts Creek study sites................................................................... 26

Table 3. Mean daily stream temperature statistics per location on Little Creek

Table 4. Hydrologic measurements on Little Creek per study reach segment. 40

Table 5. Regression analysis results, comparing heat budget components with hourly stream temperature change, on Little Creek over first $100 \mathrm{~m}$.

Table 6. Regression analysis results, comparing heat budget components with hourly stream temperature change, on Little Creek over first $300 \mathrm{~m}$

Table 7. Regression analysis results, comparing heat budget components with hourly stream temperature change, on Little Creek over $800 \mathrm{~m}$.

Table 8. Regression analysis results, comparing physical channel variables and mean daily maximum stream temperature, on Little Creek

Table 9. Modeled results of shade reduction scenarios on Little Creek at locations

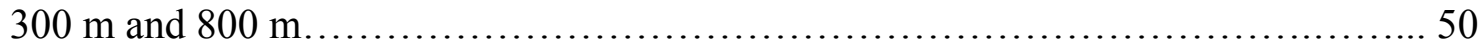

Table 10. Modeled results from groundwater inflows for 50\% and $100 \%$ shade reduction scenarios on Little Creek at location $300 \mathrm{~m}$

Table 11. Modeled results from groundwater inflows for 50\% and $100 \%$ shade reduction scenarios on Little Creek at location $800 \mathrm{~m}$ 
Table 12. Mean daily stream temperature statistics per location on Scotts Creek 52

Table 13. Hydrologic measurements on Scotts Creek per study reach segment........ 54

Table 14. Regression analysis results, comparing heat budget components with hourly stream temperature change, on Scotts Creek over first $50 \mathrm{~m} . \ldots \ldots \ldots \ldots \ldots \ldots . \ldots 5$

Table 15. Regression analysis results, comparing heat budget components with hourly stream temperature change, on Scotts Creek over first $200 \mathrm{~m}$

Table 16. Regression analysis results, comparing heat budget components with hourly stream temperature change, on Scotts Creek from locations $625 \mathrm{~m}$ to $825 \mathrm{~m} . . .59$

Table 17. Regression analysis results, comparing physical channel variables and mean daily maximum stream temperature, on Scotts Creek......................... 61

Table 18. Modeled results of shade reduction scenarios on Scotts Creek at locations 200 and $825 \mathrm{~m}$

Table 19. Modeled results from groundwater inflows for $50 \%$ and $100 \%$ shade reduction scenarios on Scotts Creek at location $200 \mathrm{~m}$ 64

Table 20. Modeled results from groundwater inflows for 50\% and 100\% shade reduction scenarios on Scotts Creek at location $825 \mathrm{~m}$ 64 


\section{LIST OF FIGURES}

Figure

Page

Figure 1. Scotts Creek Watershed with locations of Little Creek and Scotts Creek study sites.

Figure 2. Little Creek study site with locations of data collecting equipment and hydrologic measurement reaches......................................... 19

Figure 3. Scotts Creek study site with locations of data collecting equipment and hydrologic measurement reaches.

Figure 4. DTS stream temperature data (deg. C) on Little Creek from August 20 to

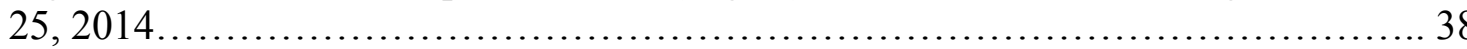

Figure 5. Minimum, maximum, $25^{\text {th }}$ and $75^{\text {th }}$ percentile, and median observed daily maximum temperatures (deg. C) per location on Little Creek

Figure 6. Observed surface, hyporheic, and groundwater temperatures at location 390 m on Little Creek.

Figure 7. Observed and modeled stream temperatures on Little Creek at location $100 \mathrm{~m}$ from August 20-25, 2014.

Figure 8. Plots of net radiation (top), heat budget components (middle), and stream temperature change (bottom) on Little Creek at location 100 m from August 20-25, 2014.

Figure 9. Observed and modeled stream temperatures on Little Creek at location $300 \mathrm{~m}$ from August 20-25, 2014

Figure 10. Plots of net radiation (top), heat budget components (middle), and stream temperature change (bottom) on Little Creek at location 300 m from August 20-25, 2014. 
Figure 11. Observed and modeled stream temperatures on Little Creek at location $800 \mathrm{~m}$ from August 20-25, 2014

Figure 12. Plots of net radiation (top), heat budget components (middle), and stream temperature change (bottom) on Little Creek at location 800 m from August 20-25, 2014.

Figure 13. Minimum, maximum, $25^{\text {th }}$ and $75^{\text {th }}$ percentile, and median observed daily maximum stream temperatures (deg. C) per location on Scotts Creek. 53

Figure 14. Observed and modeled stream temperatures on Scotts Creek at location $50 \mathrm{~m}$ from August 12-17, 2015

Figure 15. Plots of net radiation (top), heat budget components (middle), and stream temperature change (bottom) on Scotts Creek at location 50 m from August 12-17, 2015.

Figure 16. Observed and modeled stream temperatures on Scotts Creek at location $200 \mathrm{~m}$ from August 12-17, 2015.

Figure 17. Plots of net radiation (top), heat budget components (middle), and hourly stream temperature change (bottom) on Scotts Creek at location $200 \mathrm{~m}$ from August $12-17,2015$

Figure 18. Observed and modeled stream temperatures on Scotts Creek at location $825 \mathrm{~m}$ from August 12-17, 2015

Figure 19. Plots of net radiation (top), heat budget components (middle), and hourly stream temperature change (bottom) on Scotts Creek at location $825 \mathrm{~m}$ from August $12-17,2015$ 


\section{CHAPTER 1 \\ INTRODUCTION}

The thermal regime of freshwater environments support the unique combinations of flora and fauna found in aquatic ecosystems. Water temperature fluctuations result from changes in the inputs and outputs that represent a heat budget including: net radiation, latent heat (evaporation), convection (air temperature and relative humidity), advection (stream bed), and conduction (groundwater and hyporheic exchanges) (Beschta et al., 1987; Moore et al., 2005). These energy controls are inextricably linked to the hydrologic, geologic, geomorphologic, vegetative, and climatic characteristics of a watershed. Alterations to the physical landscape that affect the heat budget, can alter stream temperatures to conditions that may become adverse for cold-water fish species. Elevated stream temperatures, with respect to seasonal variations in streamflow and climate, also have the potential to create cumulative downstream effects.

A majority of coastal California watersheds have been listed as water quality impaired for stream temperature by the California Regional Water Quality Control Board (SWRCB, 2002). Riparian canopy retention has been the primary regulatory focus in stream temperature protection and has led to increased regulation of forest harvest in riparian areas. Appropriate width and canopy levels of riparian area to provide adequate stream temperature protection have been widely debated. Adaptive management strategies have been recently adopted by the California Board of Forestry to allow for more active timber management within riparian zones where management would otherwise be excluded by current watercourse and lake protection zone rules. This is in recognition that site-specific riparian management has the potential to improve instream 
aquatic habitat through increased instream cover and habitat structure from introduced woody debris, nutrient cycling, and aquatic biological productivity from increased sunlight reaching the stream channel (CDF, 2012). Active riparian management also allows for the retention of economically productive forestland while simultaneously improving and maintaining productive aquatic habitat. Implementation of site-specific restoration though is subject to evaluation and documentation of potential downstream temperature effects from the proposed management activities. This requires foresters and other land managers to use reliable methodologies and field estimates to ensure that harvest activities won't adversely affect stream temperatures among other water quality and erosion concerns.

The challenge of predicting downstream temperature effects is attempting to account for the natural spatial and temporal variability of heat energy, fate and transport, within the stream system in a manner that is practical for land managers (Webb et al., 2008). Evaluation of stream temperature controls including streamflow, stream residence times, and subsurface-surface water interactions; channel width, depth, distribution of instream features including riffles and pools; and watershed-scale characteristics including orientation, near stream climate, and drainage patterns is needed to conduct more accurate risk-based assessments. Complete analysis of all temperature controls is often not feasible for land managers due to constraints on time, resources, and expertise. In addition, traditional in-situ temperature measurements often cannot capture the spatial and temporal complexity needed for accurate risk-based assessments.

This thesis will investigate the natural controls and their relative contributions to heat energy fate and transport in the Scotts Creek Watershed in Santa Cruz County, 
California. Stream temperature, using distributed temperature sensing (DTS), hydrologic, channel morphologic, and near stream climate data were collected at two study reaches on Little Creek and Scotts Creek during the summers of 2014 and 2015. Data were used to create a comprehensive heat budget model that will aid in the study of the influences of low flow hydrology on downstream transfer of heat. In addition, an attempt was made to spatially correlate stream temperature responses with a variety of channel and valley morphologic characteristics that could potentially serve as useful and applicable indicators of downstream heating potential.

\section{Goals and Objectives}

The goal of this study is to assess the hydrologic and physical influences on summer stream temperature dynamics in the Scotts Creek Watershed and to offer suggestions for the assessment of downstream temperature effects.

Specific objectives for this study include:

1) Develop a heat budget for approximately $850 \mathrm{~m}$ stream reaches of Scotts Creek and Little Creek;

2) Assess the relative influence of hydrologic, climatic, and watershed variables on heat energy fate and transport for the stream reaches;

3) Use the heat budget model to predict temperature response and potential downstream effects from near stream vegetation removal 


\section{CHAPTER 2}

\section{STUDY LOCATION}

The Scotts Creek Watershed is located on the central coast of California in Santa Cruz County (Figure 1). The watershed encompasses $70 \mathrm{~km}^{2}$ and most closely resembles a dendritic drainage pattern with five tributaries, including Little Creek. Watershed elevations range from near sea level at the drainage outlet into the Pacific Ocean to approximately $610 \mathrm{~m}$ to the east in the Santa Cruz Mountains. The Scotts Creek study reach is located on Big Creek Lumber Company property. The Little Creek study reach is located on Cal Poly's Swanton Pacific Ranch and is primarily utilized by Cal Poly faculty and students for ongoing research and educational purposes. Uneven-aged timber management is the primary land use within Scotts Creek watershed.

\section{Climate}

Climate in the Scotts Creek Watershed is characterized by warm, dry summers and mild, wet winters. Almost all precipitation occurs as rainfall between the months of October and April with very rare occurrences of snowfall. Distribution of precipitation is largely influenced by orographic processes with annual averages ranging from $450 \mathrm{~mm}$ at the watershed outlet to $1400 \mathrm{~mm}$ at the higher elevations (Gaedeke, 2006). Localized climate can be highly variable in summer, with respect to distance from and elevation above the ocean, due to coastal fog. 

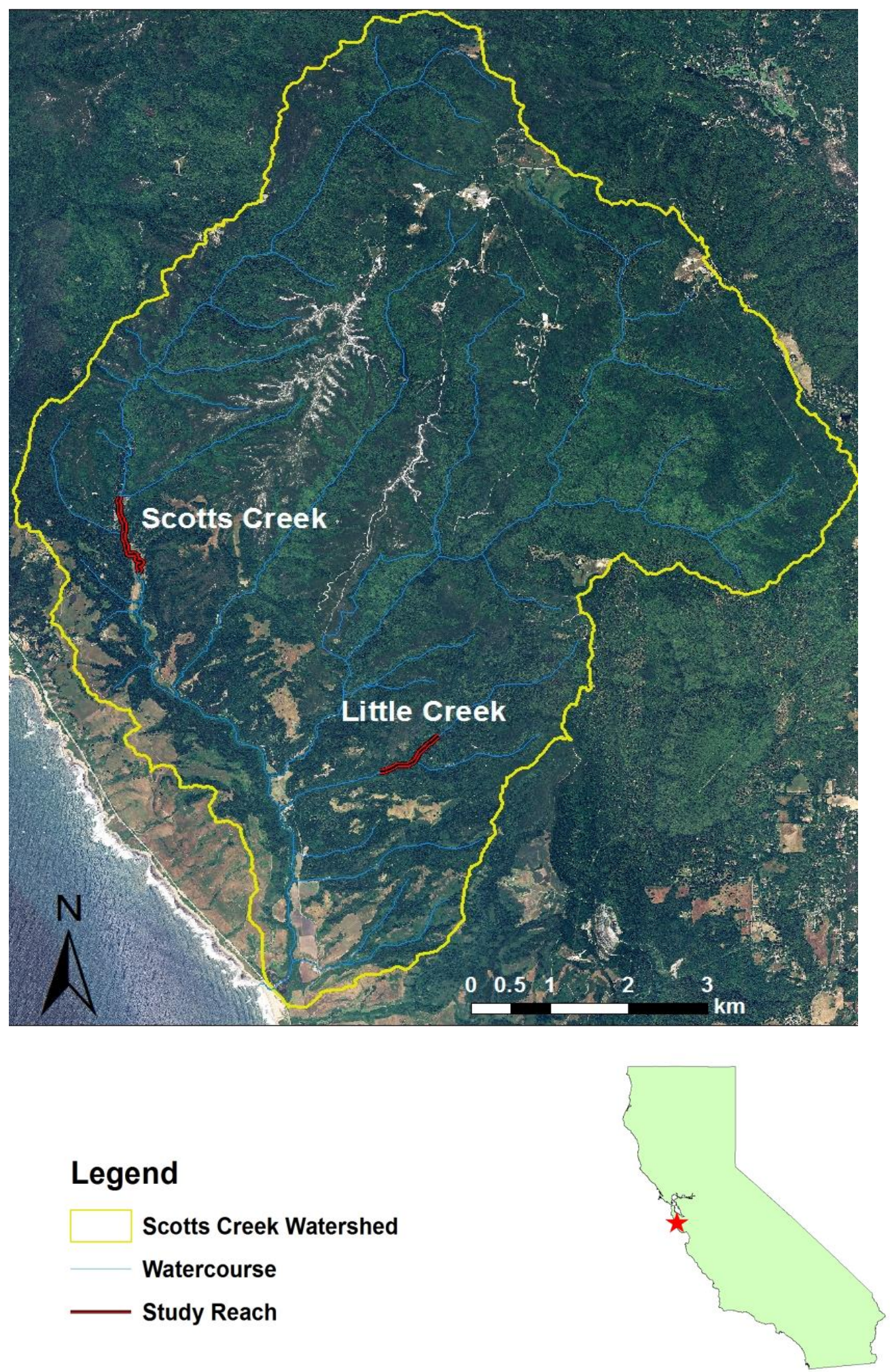

Figure 1. Scotts Creek Watershed with locations of Little Creek and Scotts Creek study sites. 
Vegetative and topographic shading also moderate summer air temperatures in riparian areas along Scotts Creek and its tributaries in contrast to drier, more exposed ridgeline areas.

\section{Geology and Geomorphology}

The Scotts Creek Watershed is located in the tectonically active Santa Cruz Mountains where rapid regional uplift and resulting stream channel incision occurs (Anderson, 1994). Scotts Creek is situated in less-confined valley bottoms with more floodplain interaction, with the exception of the uppermost area of the watershed, while Little Creek is an incised channel within a steep canyon with slopes often in excess of 70 percent. Near stream erosion and bank failure are common along most stream channel segments in the watershed due to high-intensity rainfall events and highly erodible soil parent material characteristic of the region.

Westward dipping Santa Cruz mudstone and Santa Margarita sandstone overlay igneous Ben Lomond Mountain quartzite and lesser amounts metamorphic rock (mostly schist and marble) which are exposed in lower stream valley bottoms and in the higher elevation areas along the eastern edge of the watershed (Perkins, 2012). Soils are moderately deep and well drained to excessively drained. Soil surface layers are comprised of loam, sandy loam, or stony sandy loam (Bowman and Estrado, 1976). Channel substrate along the Scotts Creek study site is mudstone-dominated with less amounts of granitic material. Channel substrate in the north fork reach of the Little Creek study site is predominantly composed of granitic material with a gradual transition towards mudstone-dominated substrate along the main stem reach. 


\section{Vegetation}

Forests within the study reaches are composed of approximately 60 percent redwood (Sequoia sempervirens), 25 percent Douglas-fir (Pseudotsuga menziesii var. menziesii), and 15 percent tanoak (Notholithocarpus densiflorus) (Piirto et al., 1999). Riparian corridors along the Scotts Creek and North Fork Little Creek study sites are predominantly redwood and Douglas-fir. Red alder (Alnus rubra), big leaf maple (Acer macrophyllum), and bay laurel (Umbellularia californica) make up a larger component of riparian vegetation along the main stem reach of Little Creek and occur to a lesser extent throughout the previously mentioned study areas.

\section{Aquatic Species of Concern}

Endangered Species Act (ESA)-listed Coho salmon (Oncorynchus kisutch) and steelhead trout (Oncorynchus mykiss) are the primary species of concern with regards to stream temperature impacts and other water quality concerns in the Scotts Creek watershed. Both species utilize Scotts Creek for spawning and juvenile development while Little Creek is primarily utilized as temporary refugia from winter storm flows in Scotts Creek where summer stream temperatures currently do not exceed levels of concern (NOAA, 2012). Both Little Creek and Scotts Creek are designated as Class I fish-bearing streams where land use practices are guided under the anadromous salmonid protection (ASP) rules of the California Forest Practices Act (CDF, 2014). McCullough et al. (2001) reported physiological stress and blockages to migration occur for Coho salmon between 19-23 deg. C and 21-24 deg. C for steelhead trout (WDOE, 2002). Direct lethality has been reported to occur for both species for mean weekly maximum 
temperatures of 23-29 deg. C (Wurtsbaugh and Davis, 1977; Bell, 1986; Welsh et al., 2001). 


\section{CHAPTER 3}

\section{LITERATURE REVIEW}

Forest riparian management policies focus on canopy retention and subsequent stream shading as the primary control in minimizing stream heating and downstream cumulative effects. Strong correlations though between stream temperature change and other environmental factors found in various studies, from both immediate and upstream sources, have made cause-effect relationships from management less certain (Sullivan and Adams, 1990; Johnson, 2003). Downstream effects on stream temperature change is further dictated by hydrologic, geomorphic, and diurnal influences and has lead to further investigations of their relative influences on stream heat fate and transport (Evans et al., 1998; Larson et al., 2002). Advancements in technology, including the use of distributed temperature sensing (DTS), and continued development of physical-based models have improved our ability to understand stream temperature spatial dynamics in an attempt to make more informed risk-based assessments for riparian management (Poole et al., 2001).

\section{Riparian Management Effects on Stream Temperature}

Many observations of local and downstream heating have been made in small, forested streams following clearcut harvests. Various before-and-after clearcut studies showed that maximum summer stream temperatures increased in magnitude, ranging from 1.8 to 11.6 deg. C, in rain-dominated watersheds in the Pacific Northwest (Harris, 1977; Feller, 1981). Johnson and Jones (2000) reported that the maximum temperature 
increased by a magnitude of $7 \mathrm{deg}$. $\mathrm{C}$ and did not return to background conditions for up to 15 years following a clearcut in the Oregon Cascades. These findings demonstrated that stream heating through increased radiation had the potential to raise stream temperatures above the thermal tolerance of some cold-water fish species and for a prolonged period of time. It was found that elevated temperatures were continually dampened with vegetative re-growth and downstream effects tended to be buffered or minimized with regards to the amount of residual upstream riparian canopy following harvest (Beschta and Taylor, 1988; Brown and Krygier, 1977; Cole and Newton, 2013; Rishel et al., 1982; Swift and Messer, 1971).

The recognized importance of stream shading prompted the continued adoption of riparian buffer widths to maximize vegetation retention along stream channels. Gomi et al. (2006) found maximum summer stream temperatures to be relatively unaffected in stream reaches with both $10 \mathrm{~m}$ and $30 \mathrm{~m}$ buffer widths of no vegetation removal compared to temperature increases, ranging from 2-8 deg. C, found in un-buffered reaches in coastal British Columbia. Partial harvesting in riparian buffers, with $10-28 \%$ of basal area removed and modest decreases in canopy density, showed an increase of 4 deg. $\mathrm{C}$ with summer maximum temperatures returning to background levels within six weeks. Little to no effects on stream temperature were observed in treatment reaches where harvesting was limited with increasing distance from the stream channel, resulting in little to no change in stream canopy coverage following harvest (Kreutzweiser et al., 2009). Pollock et al. (2009) modeled daily average maximum and diurnal temperature fluctuations in response to 40 years of various basin-wide harvesting and riparian harvesting intensities in numerous subbasins in the Hoh and Clearwater basins on 
Washington's Olympic Peninsula. While increased and prolonged downstream temperature effects were correlated with basin-wide harvesting, riparian harvesting intensities within 20 years prior to the study did not correlate well with downstream temperature effects. One stream, with $61 \%$ riparian canopy reduction upstream and conducted less than 20 years prior to the study, had one of the coolest average daily maximum temperatures at 10.9 deg. $C$ compared to another site with only $18 \%$ upstream canopy reduction, harvested less than 20 years prior, with an average daily maximum temperature of $14.1 \mathrm{deg}$. C. The latter of the previous two observations was not dissimilar to the observed average daily maximum temperature of $14.3 \mathrm{deg}$. $\mathrm{C}$ for a stream with $100 \%$ upstream riparian canopy removal. Prolonged downstream temperature effects were found in other studies comparing buffer widths and riparian canopy retention strategies and did not yield discernible differences among the treatments (Harper and Macdonald, 2002; Hewlett and Fortson, 1982) where windthrow impacts, stream aspect, and other physical watershed characteristics may have been the more influential determinants of stream buffer effectiveness (Gomi et al., 2006; Macdonald et al., 2003; Pollock et al., 2009).

Some studies have further suggested the potential influence of other explanatory variables, aside from buffer width, on moderating stream temperature change and the extent to which heat energy is transferred downstream following riparian harvest. Janisch et al. (2012) found that stream temperatures increased regardless of riparian buffer strategies in western Washington with less stream heating associated with coarser substrate material and discontinuous surface flow. This flow pattern is fairly common in forested headwater streams during summer low flow periods and is a likely indicator of 
subsurface-surface water interactions that act as a heat sink and limit the extent of downstream heat transfer. Increased daily maximum temperatures of $4 \mathrm{deg}$. $\mathrm{C}$ were only applied over relatively short distances of 600-960 m and short travel times of 2-3 hours following upstream reductions in stream shading with temperatures readily cooling as a result of increased downstream shading (Rutherford et al., 2004). Modeling of buffer width effectiveness, with solar altitude and incident radiation representative of summertime conditions in the mid-latitudes of the continental United States, indicated that buffer widths greater than $12 \mathrm{~m}$ will have a limited effect on stream shading compared to riparian vegetation height and density within the buffer (DeWalle, 2010). Although a riparian microclimate study by Brosofske et al. (1997) found that standard buffer widths of 10-90 $\mathrm{m}$ in western Oregon were inadequate in maintaining riparian microclimate, which has been shown to influence stream temperature (Anderson et al., 2007; Moore et al., 2005a).

While the importance of riparian buffers in moderating downstream temperature effects has been documented, designation of appropriate widths and canopy retention requirements are further confounded with studies that found that downstream cooling not only occurred below buffered reaches, but below non-buffered reaches. A study in interior British Columbia found stream cooling of up to 4 deg. $\mathrm{C}$ in two shaded reaches downstream of non-buffered cutblocks despite observed increases in net radiation reaching the streams (Story et al., 2003). Downstream cooling was also documented in a study by Mellina et al. (2002) where temperatures were strongly influenced by groundwater inflow regardless of upstream harvest intensity. It has been known that increases in summer lowflows occur immediately following timber harvest (Andreassian, 
2004; Keppeler and Ziemer, 1990; Rothatcher, 1970; Surfleet and Skaugset, 2013) and that increased inputs of cooler groundwater help moderate seasonal stream temperature fluctuations (Poole and Berman, 2001). Departures from earlier findings that denoted stream shading, through riparian canopy retention and stream buffer widths, as the primary variable in moderating downstream temperature effects has elicited further studies into the relative contributions of other heat budget factors to downstream cooling.

\section{Downstream Heat Transfer and Cooling Mechanisms}

Stream temperature change is a function of both heat and mass transfers within the stream network. Streamside vegetation removal promotes heat transfer through increased radiation exposure and changes to the microclimate over the stream channel and is considered to be the primary control of stream temperature (Brown, 1971; Beschta et al., 1987; Moore et al. 2005a). Stream bank stabilization is also reduced with vegetation removal and can influence channel width and depth, affecting the area of the stream that can receive effective shading from riparian canopy cover. Streamflow is the primary mass transfer mechanism of heat energy transport to downstream reaches and throughout the greater stream network. Reductions in flow from seasonal influences, anthropogenic stream diversions, and through natural gains and losses in flow volume through tributary mixing and subsurface exchanges further dictate how heat is dissipated and transported through the system. Studies have suggested that stream temperatures are not only highly sensitive to alterations for a particular stream reach, but for the greater stream network. This is in recognition that streams are not only thermally and hydrologically unique but can vary considerably for a stream network within a watershed 
of similar topography and geomorphic characteristics (Montgomery and Buffington 1997).

Stream reaches can be described as gaining or losing. In gaining stream reaches, where groundwater inputs create an increase in downstream flow, diurnal changes in stream temperatures are shown to be small. As water is transported downstream, mixing occurs with cooler groundwater and the water becomes less responsive to any heat inputs from upstream sources. The opposite effect occurs in losing reaches where decreases in total streamflow, from infiltration into the streambed, enables the water to be more susceptive stream temperature change from upstream heating. Constanz (1998) found that losing reaches tend to have greater changes in diurnal temperature due to lower streamflow where incoming solar radiation was absorbed by a decreased volume of water. Ronan et al. (1998) found that infiltration rates in losing stream reaches exhibited a diurnal fluctuation with noted temperature dependence on hydraulic conductivity of the channel substrate. Variations in upstream and downstream temperatures correlated against streambed substrate conductance were not discernible between substrate type likely due to diurnal and other hydrologic influences (Evans et al., 1998; Johnson, 2011). Heat dissipation, particularly in small headwater streams, is often linked to streamflow amount, its interaction with subsurface or tributary surface waters along its flow path, and how quickly heat is transported downstream. Channel morphologic features, such as riffles and pools, influence water mixing and stratification while other physical characteristics, such as slope and channel roughness, influence stream residence times. Spatial trends in surface-subsurface water exchange have been linked to downstream changes in slope and transitions from riffles to pools (Harvey and Bencala, 
1993) where hyporheic exchange has shown to be an important downstream cooling mechanism (Story et al., 2003; Moore et al., 2005b). Stream residence time and the influence of diurnal heat exchanges have also been found to be an important consideration in evaluating cumulative effects. Slow resident times of heated water following a clearcut in a small headwater stream in the Oregon Cascades, undergoing periods of nighttime cooling, promoted downstream maximum daily temperatures that were more associated with the cooler environment immediately downstream of the harvested area rather than the heated upstream environment (Surfleet, personal communication).

\section{Stream Temperature Measurement Development}

Developments in quantitative measurement techniques have allowed for increased understanding and monitoring of the controls in thermal behavior and thermal heterogeneity of varying spatial and temporal scales. Hydrologic processes, including groundwater exchanges and near surface exchanges in the hyporheic zone, have been effectively identified through dye trace analysis. Stream discharge, stream residence times, and transient storage have been modeled through a single trace analysis and can be effectively inferred over varying spatial extents (Laenen and Bencala, 2001). Increased ability to observe natural temperature patterns have also allowed for stream temperatures themselves to serve as suitable indicators of the spatial distribution of hydrologic controls on stream thermal behavior.

Distributed temperature sensing (DTS) has been adopted and compared against traditional methods in identifying groundwater inputs through stream temperature 
anomalies. A study by Briggs et al. (2012) demonstrated that DTS technology was able to spatially identify, and record the magnitude of groundwater inflow with the use of a dye tracer, in a large river system where modest groundwater inflow contributed 5\% of total stream discharge. DTS measurements in other studies have demonstrated its effectiveness in using temeprature to identify discrete groundwater sources and have been used in conjunction with other stream measurement techniques to quantify groundwater-surface water exchanges at the reach scale (Briggs et al., 2012; Lowry et al., 2007; Mamer and Lowry, 2013). Obtaining stream temepature measurements at finer spatial extents, through the use of DTS, has the added benefit of observing thermal heterogeneity in a stream for more comprehensive heat budget studies and in evaluating landuse effects.

Complexity of stream temperature dynamics is derived from the interrelatedness of heat budget components and their relative contributions to a stream's thermal regime. Extensive studies of stream heat budgets have identified relative contributions from individual components over a variety of spatial and temporal scales. Evaluation of the heat budget in a study in coastal British Columbia by Moore et al. (2005b) found that hyporheic exchange promoted a cooling effect with a magnitude of up to $25 \%$ that of net radiation during periods of maximum daytime warming while other heat budget components were considered to have minor influences. The authors noted that oversimplification of the heat budget model- due to an inability to account for channel geometry, canopy coverage, and spatial stream temperature heterogeneity- may have resulted in overestimation of net radiation inputs and underestimation of the magnitude of cooling fluxes during the study period. Observed seasonal and inter-annual variability in 
individual component influences on stream temperatures adds an additional dimension of complexity (Webb and Zhang, 1997).

Determining where and when streams are more vulnerable to heating and the subsequent ecological impact is needed. Spatial and temporal variability of natural stream temperature controlling factors can be identified with advancements in technology and sampling methodologies. Results from heat budget studies have lead to the development of robust deterministic models to help predict downstream cumulative effects caused by potential changes to individual components. Statistical comparisons of individual heat budget components and their controls- including channel geometry, stream shading, and stream residence times- with stream temperature change will continue to be needed when extensive physical-based modeling is not feasible. Identification of suitable stream temperature thresholds for land use policy decisions will depend on the further understanding of the influence of upstream thermal processes on potential downstream impacts at the stream reach scale (Ice et al., 2004; Boughton et al., 2012). 


\section{CHAPTER 4}

\section{METHODS}

Stream temperature, hydrologic, climate, and physical channel data were collected in the summers of 2014 and 2015 on Little Creek and Scotts Creek respectively. While some instrument setups and data collection processes differed between sites, postprocessing and calibration of the data produced a comprehensive heat budget for each system. Stream heat budget components, and channel morphology measurements were evaluated using regression analysis to determine influence on downstream heat transfer and stream temperature change for Little Creek and Scotts Creek study sites. Stream temperature, climate, and hydrologic measurements were collected at the Little Creek study site from August 20-25, 2014. The study site was $830 \mathrm{~m}$ in length, comprised of $490 \mathrm{~m}$ on the north fork of Little Creek and continued $340 \mathrm{~m}$ below the confluence of the north and south forks of Little Creek (Figure 2). Stream temperature was measured using distributed temperature sensing (DTS). A dye tracer was used to measure streamflow above and below the confluence of the North and South Forks of Little Creek to account for tributary inflow. Hydrologic processes, including average stream residence time and storage exchange rates, were modeled using dye tracer results within OTIS-P (Runkel, 1998; Runkel and Brashears, 1991) for the two dye injection locations. Discharge was also measured using a bucket and stop watch at the outlet of the South Fork of Little Creek. 

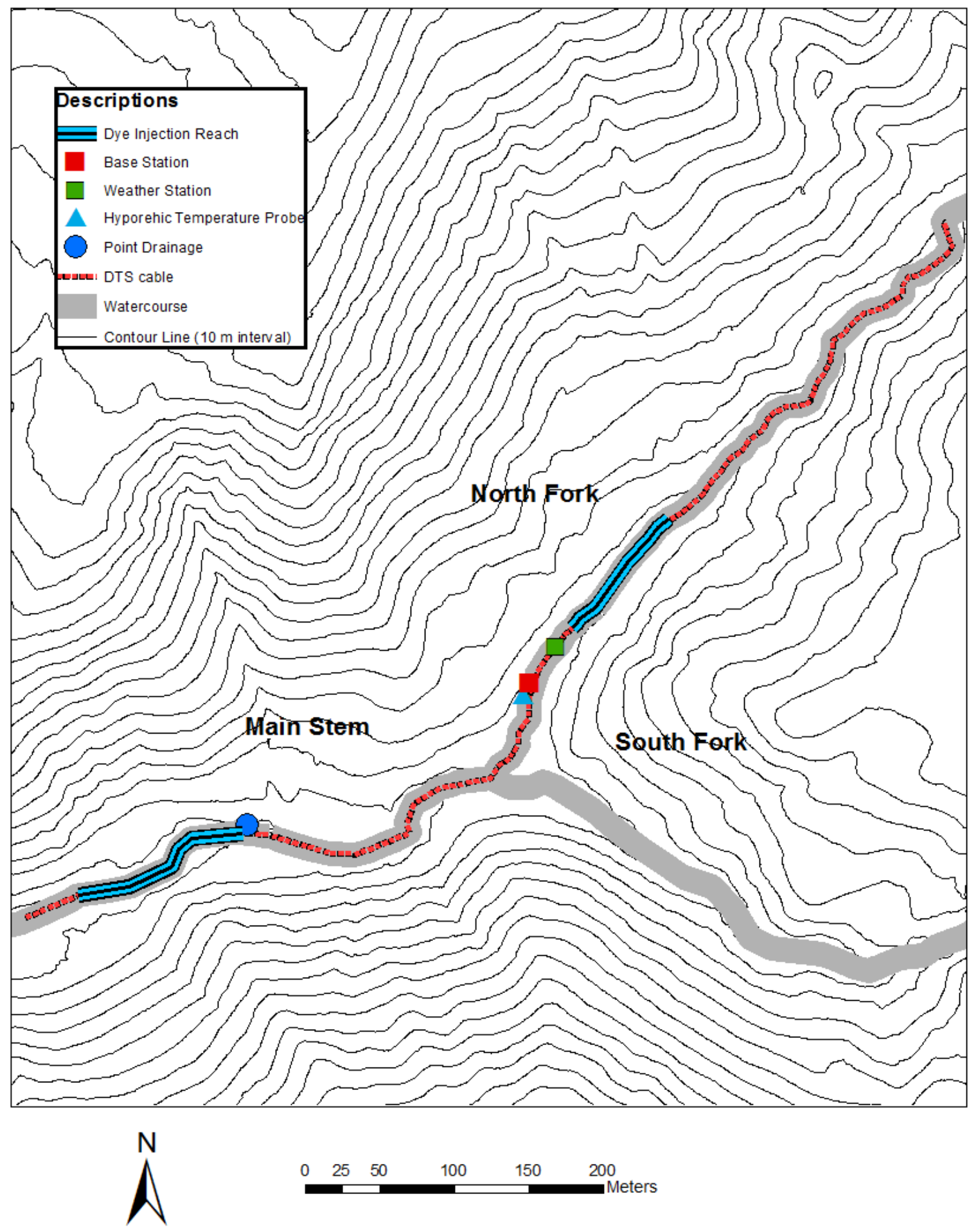

Figure 2. Little Creek study site with locations of data collecting equipment and hydrologic measurement reaches. 
Stream temperature, climate, and hydrologic measurements were collected on the Scotts Creek study site from August 12 to August 17 of 2015. A single, 1000 m DTS cable was initially deployed at the site along with a climate station and hyporheic temperature probes from July 25 to July 29 of 2015. Equipment malfunction however produced erroneous stream temperature data for only a $10 \mathrm{hr}$. period on July 25 . Seventeen Hobo temperature probes were deployed on August 12, as a compromise due to time and budget constraints, to carry out the study and to develop as close of a representation of a heat budget model for Scotts Creek under summer low flow conditions. Data were collected on two, $200 \mathrm{~m}$ reaches over an entire study site length of $825 \mathrm{~m}$ where the upper reach spanned from 0 to $200 \mathrm{~m}$ and the lower reach from $625 \mathrm{~m}$ to $825 \mathrm{~m}$ (Figure 3).

\section{Stream Temperature Measurement}

\section{Little Creek Study Site}

Stream temperatures were recorded using distributed temperature sensing (DTS). DTS is the use of a fiber optic cable to continuously measure temperature, through application of Stoke's Law, along transects at sub-meter scales (Selker, 2009; Tyler et al., 2009). The DTS was deployed with two fiber-optic cables extending from a base station, situated in the middle of the study reach, with one cable extending upstream (upper segment) and the other downstream (lower segment). The cable was placed on the stream bed along the thalweg of the stream channel. Cable segments affected by air temperature, from segments of the cable which could not be submerged due to large debris and sediment jams, were later omitted from the dataset during post-processing. 


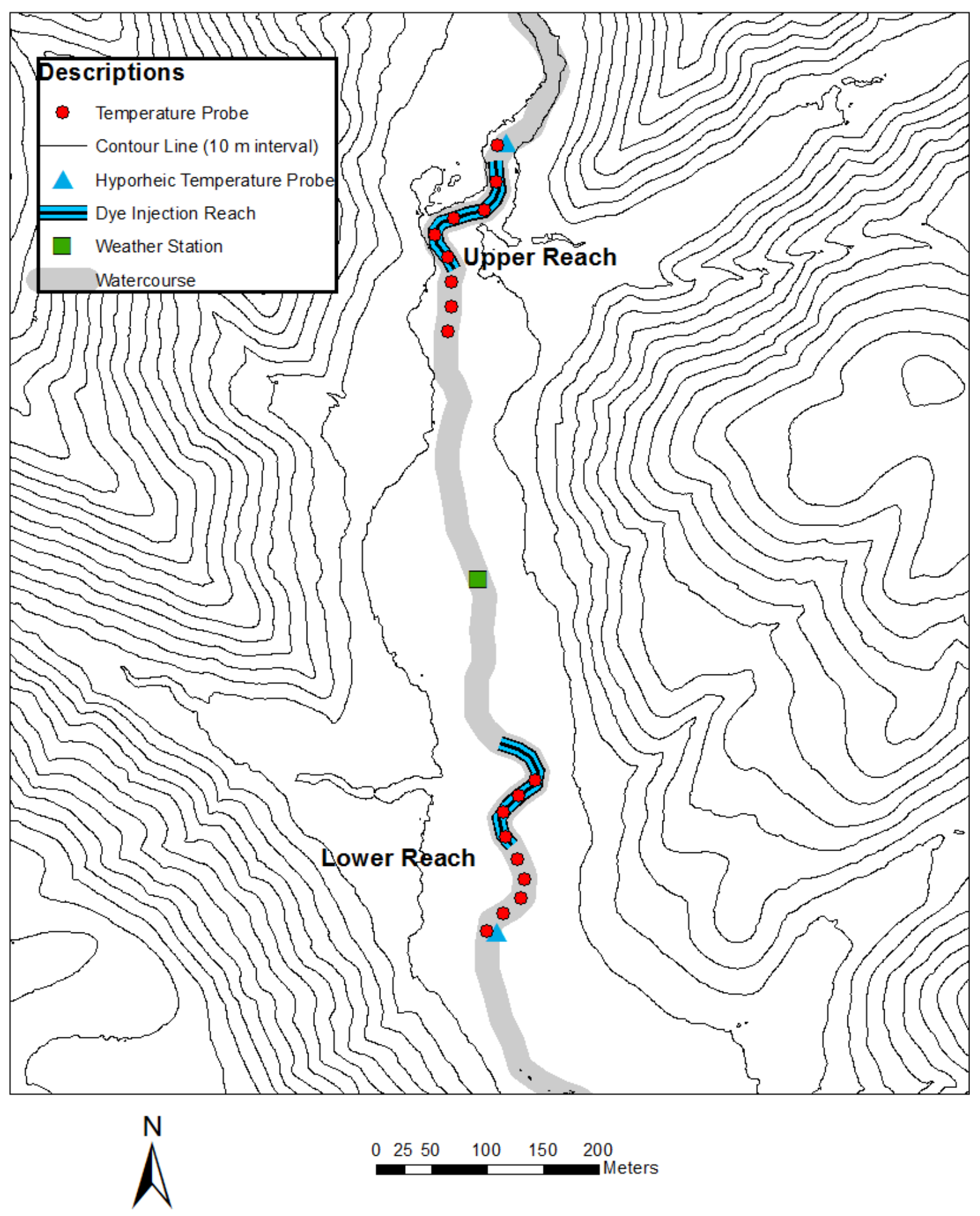

Figure 3. Scotts Creek study site with locations of data collecting equipment and hydrologic measurement reaches. 
Approximately $20 \mathrm{~m}$ of fiber optic cable were coiled at end of each segment extending from the base station and approximately $10 \mathrm{~m}$ of cable were coiled at the other end of each segment as part of the post-processing calibration routine. Ten meters of coiled cable at the base station, one for each segment, was placed in a calibration bath filled with ice water ( $\sim 0 \mathrm{deg}$. C). The remaining $20 \mathrm{~m}$ of coiled cable for each segment, at the base station and upstream or downstream ends, were placed in a separate calibration bath filled with water from Little Creek. Calibration baths were insulated to maintain constant temperatures and were equipped with a bubbler to prevent temperature stratification. Temperatures of the calibration baths were recorded every 15 min. with a Hobo sensor placed in each bath.

DTS output was transferred to MATLAB (MathWorks Inc.) where a calibration routine provided by the Center for Transformative Environmental Monitoring Program (CTEMP) was used to calibrate and convert the raw Stokes and anti-Stokes data into stream temperature in degrees Celsius. Processed data were created in a vector format along with separate vectors for the timestamp and distance.

Table 1. DTS post-processing calibration statistics in deg. C.

\begin{tabular}{|lcc|}
\hline $\begin{array}{l}\text { DTS cable } \\
\text { segment }\end{array}$ & RMSE & Bias \\
\hline Upper & 0.061 & $1.357 \mathrm{E}-05$ \\
Lower & 0.088 & $2.912 \mathrm{E}-05$ \\
\hline
\end{tabular}


Post-processing was completed on both channels using the single-ended method developed by Hausner et al. (2011) where sections of reference temperatures, recorded in calibration baths, were used to reduce noise in the stream temperature data. Root Mean Square Error (RMSE) and bias were calculated from the processed data for both calibration and validation tests (Table 1). The validation test used a section of cable in the warm bath at the end of the cable and is independent of the data used for the calibration. Calibrated stream temperatures were scaled to a spatial resolution of $5 \mathrm{~m}$ to coincide with the physical channel measurements collected at $5 \mathrm{~m}$ intervals. Stream temperatures at the $1 \mathrm{~m}$ scale were not averaged per $5 \mathrm{~m}$ interval.

Hyporheic temperature measurements were collected with a Hobo temperature sensor ( $\pm 0.2 \mathrm{deg}$. C accuracy) adjacent to the DTS base station. These sensors were buried at a depth of approximately $.25 \mathrm{~m}$ along sand and gravel bars, about $1.5-2 \mathrm{~m}$ away from the active stream channel, to provide a representation of temperature for water which undergoes both downwelling and upwelling within the study reach. A temperature sensor was also buried in a groundwater seepage area in a location upslope of the study site to provide temperature of local groundwater.

\section{$\underline{\text { Scotts Creek Study Site }}$}

Stream temperatures were recorded with Hobo temperature sensors $( \pm 0.2$ deg. C accuracy) at $15 \mathrm{~min}$. intervals. Probes were placed at $25 \mathrm{~m}$ intervals within the upper and lower $200 \mathrm{~m}$ reaches along the thalwag of the active channel. Hyporheic temperature data were collected with Hobo temperature sensors from July 25-29 at upper and lower ends 
of the study site (locations 0 and $825 \mathrm{~m}$ ). These sensors were buried at a depth of approximately $.25 \mathrm{~m}$ along sand and gravel bars, about five to six feet away from the active stream channel, to provide a representation of temperature for water which undergoes both downwelling and upwelling within each study reach. It was assumed that an average hyporheic temperature at both locations, given the dampened fluctuations in daily minimum and maximum temepratures compared to surface water temperatures, would suffice as representative hyporheic temperatures from August 12 to 17. Average groundwater temperature observed at the Little Creek study site in August of 2014, assumed to be representative of regional groundwater temperatures within the greater Scotts Creek Watershed, was used for heat budget model development for Scotts Creek.

\section{Streamflow and Hydrologic Processes}

A constant-rate injection method, using Rhodamine WT as a tracer, was used to measure streamflow, stream residence time, and relative amounts of surface-subsurface exchanges occurring along two sections of Scotts Creek and Little Creek study sites. Complete mixing of the dye tracer in the water column ensured that water storage areas and irregular flow patterns, including those found in pools and riffle sections, were accounted for in determining accurate flow measurements. A known concentration of dye was injected into the stream at a constant rate with a peristaltic pump (Solinst Canada Ltd.) where instream dye concentrations and background stream concentrations were recorded every $60 \mathrm{~s}$ at the downstream end of each section with a Cyclops fluorometer (Turner Designs) with a precision of $1 \mathrm{ppb}$. Dye was continuously injected for upwards 
of a few days to achieve steady-state conditions and full mixture in the stream. The published USGS mass-balance equation for constant-rate injection (Kilpatrick and Cobb, 1985) was used to calculate streamflow (equation 1):

$$
Q \frac{c_{1}-c_{2}}{c_{2}-c_{b}} * q
$$

where $\mathrm{Q}=$ measured streamflow $\left(\mathrm{L} \mathrm{s}^{-1}\right), \mathrm{c}_{1}=$ initial concentration of injected dye solution $\left(\mu \mathrm{g} \mathrm{L}^{-1}\right), \mathrm{c}_{2}=$ steady-state instream dye concentration $\left(\mu \mathrm{g} \mathrm{L}^{-1}\right), \mathrm{c}_{\mathrm{b}}=$ background concentration of the stream before dye was injected $\left(\mu \mathrm{g} \mathrm{L}^{-1}\right)$, and $\mathrm{q}=$ injection rate of the $\operatorname{pump}\left(\mathrm{ml} \mathrm{min} .^{-1}\right)$.

The dye injection record for each study site (Table 2) was input into the United States Geological Survey (USGS) one-dimensional transport model with inflow and storage (OTIS). OTIS is a transient storage model simulating the effect of the temporary detainment of solutes in small eddies, stagnant pockets of water, or porous areas of the streambed. These areas of storage can be stationary relative to the faster moving waters near the center of the channel (Runkel, 1998). The timing and volume of transient storage can have an effect on increasing or decreasing solar radiation water receives as it travels downstream. Further, mixing of groundwater can alter water temperature through advection based on differences in groundwater temperature relative to surface water temperatures.

The OTIS-P version of OTIS was used with our dye tracer injection results. OTIS-P. The OTIS-P model couples the mathematical framework of OTIS with the NLS algorithms of STARPAC (Donaldson and Tryon, 1990). OTIS-P thereby provides an automated means of estimating model parameters. Through iterations of model runs 
OTIS-P provides parameters associated with transient storage calculations that provide the best fit to our measured dye results. Model parameters used in this study were:

$$
\begin{aligned}
& A_{s}=\text { cross section area of storage zone }\left(\text { Length }^{2}\right) \\
& \alpha=\text { storage zone exchange coefficient (1/time) } \\
& \text { Lamda }=\text { first order decay coefficient for dye in main channel } \\
& \text { Lamda2 = first order decay coefficient for dye in storage zone. }
\end{aligned}
$$

From the parameters hyporheic exchange $\left(\mathrm{q}_{\mathrm{s}}\right)$ can be calculated with the following method (equation 2) by Harvey et al. (1996):

$$
\mathrm{q}_{\mathrm{s}} \quad \alpha \mathrm{A}
$$

where $\mathrm{A}=$ cross section area of surface water $\left(\mathrm{Length}^{2}\right)$.

The fluid residence time $\left(t_{s}\right)$ is estimated by (equation 3$)$ :

$$
\mathrm{t}_{\mathrm{s}}=\mathrm{A}_{\mathrm{s}} / \mathrm{q}_{\mathrm{s}}
$$

Table 2. Dye tracer measurement parameters for Little Creek and Scotts Creek study sites.

\begin{tabular}{|lccccccc|}
\hline $\begin{array}{l}\text { Little Creek Dye } \\
\text { tracer reach }\end{array}$ & $\mathrm{c}_{1}\left(\mu \mathrm{g} \mathrm{L}^{-1}\right)$ & $\mathrm{c}_{2}\left(\mu \mathrm{g} \mathrm{L}^{-1}\right)$ & $\mathrm{c}_{\mathrm{b}}\left(\mu \mathrm{g} \mathrm{L}^{-1}\right)$ & $\mathrm{q}\left(\mathrm{ml} \mathrm{min} .^{-1}\right)$ & $\mathrm{A}\left(\mathrm{m}^{2}\right)$ & $\mathrm{A}_{\mathrm{s}}\left(\mathrm{m}^{2}\right)$ & $\mathrm{L}(\mathrm{m})$ \\
\hline North Fork & $2.508 \mathrm{E}+04$ & 73.94 & 0.08 & 468 & 0.083 & 4.544 & 102 \\
Main Stem & $2.475 \mathrm{E}+04$ & 33.35 & 0.11 & 450 & 0.138 & 4.989 & 119 \\
South Fork & $2.508 \mathrm{E}+04$ & 76.84 & 0.09 & 420 & - & - & - \\
\hline $\begin{array}{l}\text { Scotts Creek } \\
\text { Dye tracer reach }\end{array}$ & $3.200 \mathrm{E}-05$ & 96.00 & 0.20 & 15 & 0.278 & 0.205 & 80 \\
\hline $\begin{array}{l}\text { Upper } \\
\text { Lower }\end{array}$ & $3.200 \mathrm{E}-05$ & 82.20 & 0.24 & 15 & 0.200 & 0.200 & 84 \\
\hline
\end{tabular}


Groundwater input was determined by the difference in streamflow from the upper to lower ends of the study reach.

\section{Climate Measurements}

A portable weather station was situated at the middle of each study site and was outfitted with individual sensors for recording air temperature (deg. C), relative humidity $(\%)$, and wind speed $\left(\mathrm{m} \mathrm{s}^{-1}\right)$. Net radiation data for both of the Little Creek and Scotts Creek study periods were obtained from CIMIS climate station 104 located in eastern Santa Cruz in the De Laveaga golf course (CIMIS, 2016). Radiation data were collected under open sky conditions ( $0 \%$ shading) and were extrapolated, based on the observed 25 $\mathrm{m}$ stream shading figures, for each stream temperature location in the study site.

\section{$\underline{\text { Little Creek Study Site }}$}

Mean air temperature of $15.7 \mathrm{deg}$. C, relative humidity of $89.6 \%$ and negligible wind speed $\left(<0.01 \mathrm{~m} \mathrm{~s}^{-1}\right)$ were observed during the study period. No precipitation occurred during the study period.

\section{$\underline{\text { Scotts Creek Study Site }}$}

Climate data were initially collected at $15 \mathrm{~min}$. intervals using a portable Hobo weather station (Onset) from July 25 to July 29. The weather station was situated at the middle of the study site at an approximate location of $400 \mathrm{~m}$. Average relative humidity $85.5 \%$ and average wind speed of $0.12 \mathrm{~m} \mathrm{~s}^{-1}$ were computed from data collected during the initial July period were assumed to be representative for the August study period. Air temperature for the August study period was recorded with two Hobo temperature 
sensors located at both the upper and lower reaches. Mean air temperatures observed during the study period at the upper and lower reaches were 17.9 and $18.5 \mathrm{deg}$. C respectively. No precipitation was observed during the study period.

\section{Physical Channel Measurements}

A variety of physical channel parameters were measured at varying intervals along each study site and used to observe statistical correlations with spatial trends in mean daily maximum stream temperatures. Active channel width (m) and average stream depth $(\mathrm{m})$, determined from three depth measurements along the cross-section of the active stream channel, were recorded at $5 \mathrm{~m}$ intervals along the study reach along with the aspect (width over depth) ratio. Bankfull and floodprone widths (m) were measured every $25 \mathrm{~m}$ using physical indicators and a regional curve (Dietterick, 2008) as a guide. Percent stream shading over the active channel from the overstory canopy was recorded using the August solar path on a solar pathfinder at $25 \mathrm{~m}$ intervals. Stream shading was also recorded at the weather station location and used as a relative comparison to net radiation at each $25 \mathrm{~m}$ stream shading measurement point.

Physical channel measurements were not made at locations where debris and sediment jams prevented the DTS cable from being submerged. The relative location of measurement points and sediment and debris jams to the DTS cable was noted to aid in spatially rectifying stream temperature and physical channel data. A uniform sampling interval, as opposed to determining sampling intervals by stream habitat features, was determined to be the least biased and most easily repeatable approach for future studies. 


\section{Heat Budget Model}

Spatially explicit stream temperature, climate, hydrologic, and physical channel data were used to develop a comprehensive heat budget model by calculating individual components of heat flux for both study reaches using equations developed by Moore et al. (2005b). Modeled downstream temperature change was determined by the stream reach's combined heat and water budgets (equation 4) expressed as:

$$
\frac{d T}{d t} \quad \frac{\left(q_{s}-q_{h y}\right)\left(T_{u s}-T_{d s}\right)}{n d L}+\frac{Q_{*}+Q_{h}+Q_{e}+Q_{c}+Q_{g w}+Q_{h y p}}{\rho c_{p} d}
$$

where $\mathrm{q}_{\mathrm{s}}=$ streamflow $\left(\mathrm{m}^{3} \mathrm{~s}^{-1}\right), \mathrm{q}_{\mathrm{hyp}}=$ hyporheic flow $\left(\mathrm{m}^{3} \mathrm{~s}^{-1}\right), \mathrm{T}_{\mathrm{us}}=$ upstream temperature through time (deg. $C), T_{d s}=$ downstream temperature through time (deg. C), $\mathrm{w}=$ width of the active channel $(\mathrm{m}), \mathrm{d}=$ stream depth $(\mathrm{m}), \mathrm{L}=$ reach length $(\mathrm{m}), \mathrm{Q} *=$ net radiation $\left(\mathrm{W} \mathrm{m}^{-2}\right), \mathrm{Q}_{\mathrm{h}}=$ sensible heat flux from overlying air $\left(\mathrm{W} \mathrm{m}^{-2}\right), \mathrm{Q}_{\mathrm{e}}=$ latent heat exchange $\left(\mathrm{W} \mathrm{m}^{-2}\right), \mathrm{Q}_{\mathrm{c}}=$ streambed heat conduction $\left(\mathrm{W} \mathrm{m}^{-2}\right), \mathrm{Q}_{\mathrm{gw}}=$ heat flux associated with groundwater inflow $\left(\mathrm{W} \mathrm{m}^{-2}\right), \mathrm{Q}_{\text {hyp }}=$ heat flux associated with hyporheic exchange $\left(\mathrm{W} \mathrm{m} \mathrm{m}^{-2}\right), \rho=$ water density $\left(\mathrm{kg} \mathrm{m}^{-3}\right)$, and $\mathrm{c}_{\mathrm{p}}=$ specific heat of water $\left(\mathrm{J} \mathrm{kg}^{-1} \mathrm{~K}^{-1}\right)$. Equations used to calculate individual heat budget components can be referenced in Moore et al. (2005b).

\section{$\underline{\text { Little Creek Study Site }}$}

A time step of $1 \mathrm{hr}$. and distance step of $100 \mathrm{~m}$ were determined to be the most appropriate parameters to model stream temperature change over the entire Little Creek study area based on average stream residence times determined from OTIS-P modelling 
and the observed distances over which the dye tracer analysis occurred. This approach was believed to be the most appropriate and effective means of modelling and evaluating downstream heat transport given that stream temperatures and their relative change through time at a given location is a product of heat fluxes occurring at that location and from the upstream environment. Stream temperatures were therefore modeled at $100 \mathrm{~m}$ intervals from locations 0 (upstream North Fork) to $800 \mathrm{~m}$ (downstream Main Stem) at 1 hr. intervals.

Previously measured stream depths and widths per $100 \mathrm{~m}$ locations were used for determining appropriate physical channel characteristics within the heat budget model. Air temperature, relative humidity, and wind speed data collected from the weather station were assumed to be representative of climate conditions for the $800 \mathrm{~m}$. Hyporheic temperature and computed streambed conductivity temperatures, collected at an approximate location of $400 \mathrm{~m}$, were assumed to be representative for the $800 \mathrm{~m}$. Streamflow and hyporheic exchange rate values were assumed to be representative for all $100 \mathrm{~m}$ locations within the respective North Fork and Main Stem reaches.

Individual heat budget components, along with $100 \mathrm{~m}$ net radiation values, were then computed for every $100 \mathrm{~m}$ location to model temperature change per hour. Modeled stream temperature per $100 \mathrm{~m}$ location were then computed by adding the sum of modeled temperature changes, occurring between the modeled temperature location and location $0 \mathrm{~m}$, with the observed temperature at location $0 \mathrm{~m}$. 


\section{$\underline{\text { Scotts Creek Study Site }}$}

Distance and time steps of $100 \mathrm{~m}$ and $1 \mathrm{hr}$. were not applicable for modeling heat transfer for Scotts Creek due to much longer observed stream residence times (Table in Results). Stream temperature change and subsequent modeled temperatures were modeled at $25 \mathrm{~m}$ intervals every hour to utilize available data and to potentially serve as a comparison with the modeling approach at Little Creek, where distance and time steps were based on the hydrologic conditions of the system.

Previously measured stream depths and widths per $25 \mathrm{~m}$ locations were used for determining appropriate physical channel characteristics within the heat budget model. Air temperature data, collected at both the upper and lower reaches, were assumed to be representative for the respective reach where data were collected. Average relative humidity and wind speed collected from the weather station during the July study period were assumed to be representative of climate conditions for the August study period for both the upper and lower reaches. Average hyporheic temperature and computed average streambed conductivity temperature along with streamflow and hyporheic exchange rate values, determined from data collected at both the upper and lower reaches during the initial July study period, were assumed to be representative for the August period for the respective reach where hydrologic processes were measured.

Individual heat budget components, along with $25 \mathrm{~m}$ net radiation values, were then computed for every $25 \mathrm{~m}$ location to model temperature change per hour. Modeled stream temperatures per $25 \mathrm{~m}$ location were computed by adding modeled temperature change to the modeled temperature values occurring $1 \mathrm{hr}$. prior. Computed temperature 
change occurring between locations 225 and $625 \mathrm{~m}$ was found to be adequate in carrying modeled temperatures from the upper reach to the lower reach.

\section{Statistical Analysis and Modelling Downstream Effects}

Regression analysis was used to compare and evaluate individual heat budget and physical channel variable influences on both downstream temperature changes through time and the spatial distribution of maximum stream temperatures. Variance inflation factors (VIF) and Eigenvalues were used to evaluate the degree of multicollinearity among independent variables. Variable(s) were removed from the regression analyses if multicollinearity was detected to provide better model fit and coefficient estimates.

\section{Little Creek Study Site}

Downstream temperature change at 100,300 , and $800 \mathrm{~m}$ were statistically compared against averaged heat budget components over the respective distance. Individual heat budget components occurring at each location were averaged with the individual heat budget components occurring at each previous distance and time step (i.e. $100 \mathrm{~m}$ upstream $1 \mathrm{hr}$. prior, $200 \mathrm{~m}$ upstream $2 \mathrm{hrs}$. prior, etc.) up to the location and time associated with the distance. This approach remained consistent with our assertion, based on the average residence time and designated time and distance steps for Little Creek, that it would take $1 \mathrm{hrs}$. for water to travel $100 \mathrm{~m}$. Temperature change over $800 \mathrm{~m}$, as an 
example, was defined as the temperature at location $800 \mathrm{~m}$ minus the temperature $8 \mathrm{hrs}$. prior at location $0 \mathrm{~m}$.

Mean maximum, minimum, and average daily stream temperatures were statistically compared against measured physical channel characteristics at each $25 \mathrm{~m}$ location throughout the study reach. Mean daily or weekly maximum temperatures are commonly used indicators for monitoring and regulating potential stream temperature impacts, particularly for cold-water aquatic species, and provide an effective and repeatable measure for potentially assessing stream reaches that are naturally more susceptible to heating.

Potential downstream effects at locations $300 \mathrm{~m}$ and $800 \mathrm{~m}$ were also modeled by implementing hypothetical scenarios in which stream shading was reduced, via canopy reduction from timber harvest or forest fire, along the first $300 \mathrm{~m}$ of the study site. This section along the North Fork of Little Creek is managed by Swanton Pacific Ranch for both timber production and ecological restoration. Two scenarios were modeled by recomputing net radiation values corresponding to both a $50 \%$ and $100 \%$ reduction in stream shading over the $300 \mathrm{~m}$ segment. These figures would more than likely exceed the allowable reduction in timber canopy for a class I watercourse within the California Forest Practice Rules, but serve as an informative assessment of how downstream temperatures potentially respond to upstream heating and comparative measure to demonstrate potential effects from current uneven-aged timber management and future habitat restoration work. Deviations of mean daily maximum, minimum, and average stream temperatures modeled under the shading reduction scenarios from present 
conditions were used to evaluate the magnitude and spatial distribution of downstream effects.

An additional analysis was performed by implementing hypothetical scenarios in which groundwater inflows would increase following near-stream vegetation removal, presumably from decreased evapotranspiration, along the first $300 \mathrm{~m}$ of the study site. Stream temperatures were modeled with groundwater inflow increases of $10 \%, 20 \%$, $30 \%$, and $50 \%$ under both the $50 \%$ and $100 \%$ shade reduction scenarios. Groundwater flow rates were computed as a percentage of total observed surface water flow and were used along with the mean observed groundwater temperature to predict the temperature response at both $300 \mathrm{~m}$ and $800 \mathrm{~m}$ using a standard temperature mixing equation (equation 5) as follows:

$$
T_{\text {model }}=\frac{T_{s} Q_{S}+T_{g w} Q_{g w}}{Q_{s}+Q_{g w}}
$$

where $\mathrm{T}_{\text {model }}=$ modeled groundwater scenario temperature $($ deg. $C), T_{\mathrm{s}}=$ modeled surface water temperature for specified shade reduction scenario (deg. C), $Q_{s}=$ surface water flow $\left(\mathrm{m}^{3} \mathrm{~s}^{-1}\right), \mathrm{T}_{\mathrm{gw}}=$ mean observed groundwater temperature (deg. C), and $\mathrm{Q}_{\mathrm{gw}}=$ computed groundwater inflow $\left(\mathrm{m}^{3} \mathrm{~s}^{-1}\right)$.

Deviations of mean daily maximum, minimum, and average stream temperatures modeled under the groundwater inflow scenarios from the modeled temperatures with no groundwater inflow, under both $50 \%$ and $100 \%$ shade reduction scenarios, were used to evaluate the magnitude and spatial distribution of downstream effects. 


\section{$\underline{\text { Scotts Creek Study Site }}$}

Downstream temperature change at locations 50 and $200 \mathrm{~m}$ were statistically compared against averaged heat budget components over the respective distance. Individual heat budget components occurring at each location were averaged with the individual heat budget components occurring at each previous distance and time step (i.e. $25 \mathrm{~m}$ upstream $1 \mathrm{hr}$. prior, $50 \mathrm{~m}$ upstream $2 \mathrm{hrs}$. prior, etc.) up to the location and time associated with each distance. Temperature change over the entire $825 \mathrm{~m}$ of the Scotts Creek study site could not be modeled effectively due to the longer observed stream residence times. Temperature change was therefore evaluated separately for the lower reach (location 625 to $825 \mathrm{~m}$ ). Mean daily maximum, minimum, and average stream temperatures were statistically compared against measured physical channel characteristics at each $25 \mathrm{~m}$ location throughout both study reaches.

Potential downstream effects were modeled at locations $200 \mathrm{~m}$ and $825 \mathrm{~m}$ by implementing hypothetical scenarios in which stream shading was reduced, via canopy reduction from timber harvest or forest fire, along the first $200 \mathrm{~m}$ (upper reach). Modeled temperature change carried through the $400 \mathrm{~m}$ between the upper and lower reaches had to be assumed to predict representative modeled temperatures within the lower reach. Two scenarios were modeled by re-computing net radiation values corresponding to both a $50 \%$ and $100 \%$ reduction in stream shading over the first $200 \mathrm{~m}$ of the study area. Deviations of mean daily maximum, minimum, and average stream temperatures modeled under the shading reduction scenarios from modeled temperatures under present conditions were used to evaluate the magnitude and spatial distribution of downstream effects. 
Additionally, an analysis was performed by implementing hypothetical scenarios in which groundwater inflows would increase following near-stream vegetation removal along the first $200 \mathrm{~m}$ of the study site. Stream temperatures were modeled with groundwater inflow increases of $10 \%, 20 \%, 30 \%$, and $50 \%$ under both the $50 \%$ and $100 \%$ shade reduction scenarios to predict temperature response at locations $200 \mathrm{~m}$ and $825 \mathrm{~m}$ using the approach described for the Little Creek study site. 


\section{CHAPTER 5}

\section{RESULTS}

\section{Little Creek}

Stream temperatures during the August 20 to 25 study period of 2014 exhibited expected trends in thermal dynamics for a cold-water, forested stream in coastal California. Stream temperatures on average fluctuated less than $2 \mathrm{deg}$. C for any given location throughout the study site with mean daily maximum temperature of $15.46 \mathrm{deg}$. $\mathrm{C}$ and mean daily minimum temperature of $14.28 \mathrm{deg}$. C observed throughout the study period. Mean daily average temperature for the entire study site was $14.72 \mathrm{deg}$. C. Temporal patterns in stream temperatures were found to be consistent with expected diurnal fluctuations observed in most systems with daily maximum temperature for a given location occurring between 14:00 and 15:00, coinciding with the timing of daily maximum net radiation for that location. The rate of daily diurnal cooling and heating remained consistent between observed days during the study period for all locations (Figure 4). Daily maximum and minimum temperatures however were found to vary spatially ranging from a daily maximum temperature of $16.21 \mathrm{deg}$. $\mathrm{C}$ at location $800 \mathrm{~m}$ to 14.97 deg. $\mathrm{C}$ at location $200 \mathrm{~m}$ (Figure 5; Table 3). While heating and subsequent cooling occurs between all locations as water moves downstream, DTS temperature data observed over the entire $825 \mathrm{~m}$ reveals a net warming trend in daily maximum temperatures as water moves downstream with no discernible heating or cooling trend in daily minimum temperatures. 


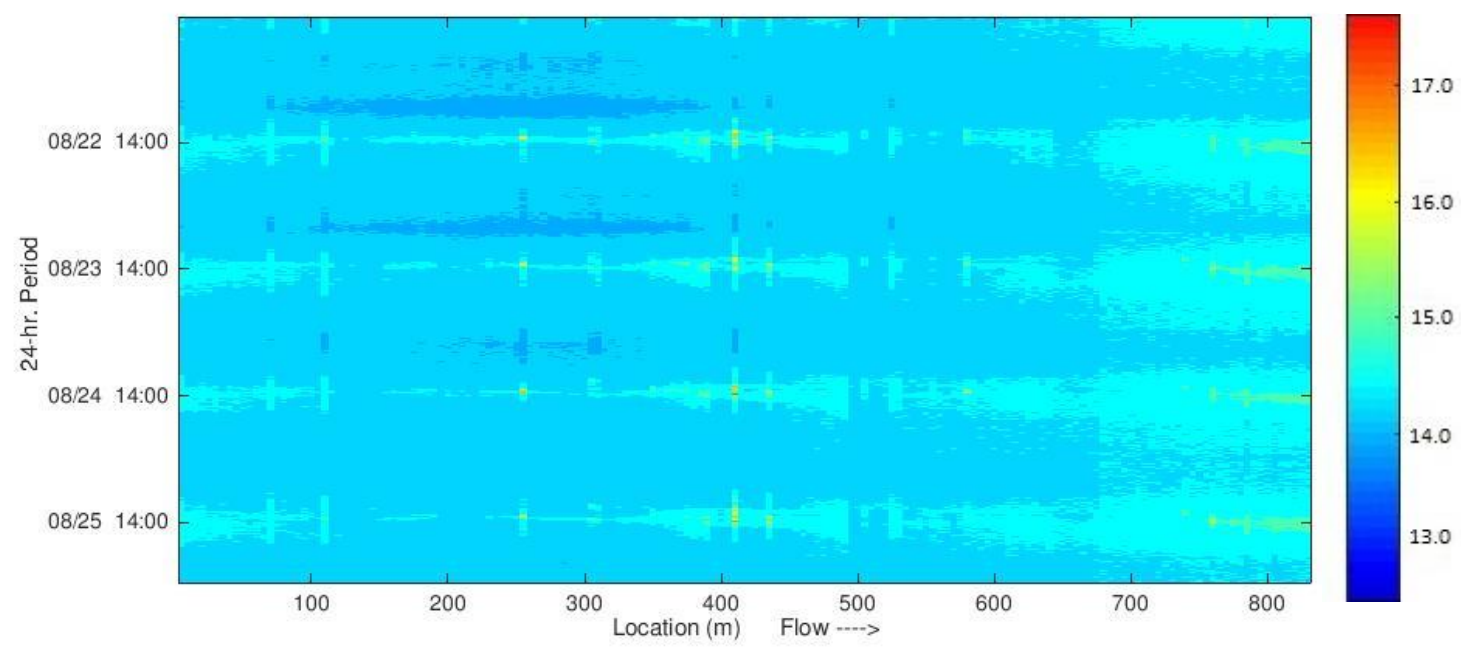

Figure 4. DTS stream temperature data (deg. C) on Little Creek from August 20 to 25, 2014.

Daily trends in surface water temperature compared to hyporheic water temperature, observed at location $390 \mathrm{~m}$, exhibited expected patterns in subsurfacesurface thermal dynamics as diurnal fluctuations dampened with depth and less exposure to solar radiation (Figure 6). Mean daily average temperatures of 14.87, 15.28, and 14.73 deg. $\mathrm{C}$ were observed during the study period for surface, hyporheic, and groundwater respectively. Timing of maximum and minimum hyporheic temperatures were also found to be lagged behind maximum and minimum surface water temperatures. This observation, along with higher daily average hyporheic temperatures despite larger surface water peak temperatures, may indicate that heat entering the hyporheic zone from the surface environment may reside longer in the subsurface and at times create a net heating effect in the system, particularly when regional groundwater temperatures only deviate from surface and hyporheic averages by less than a degree. 


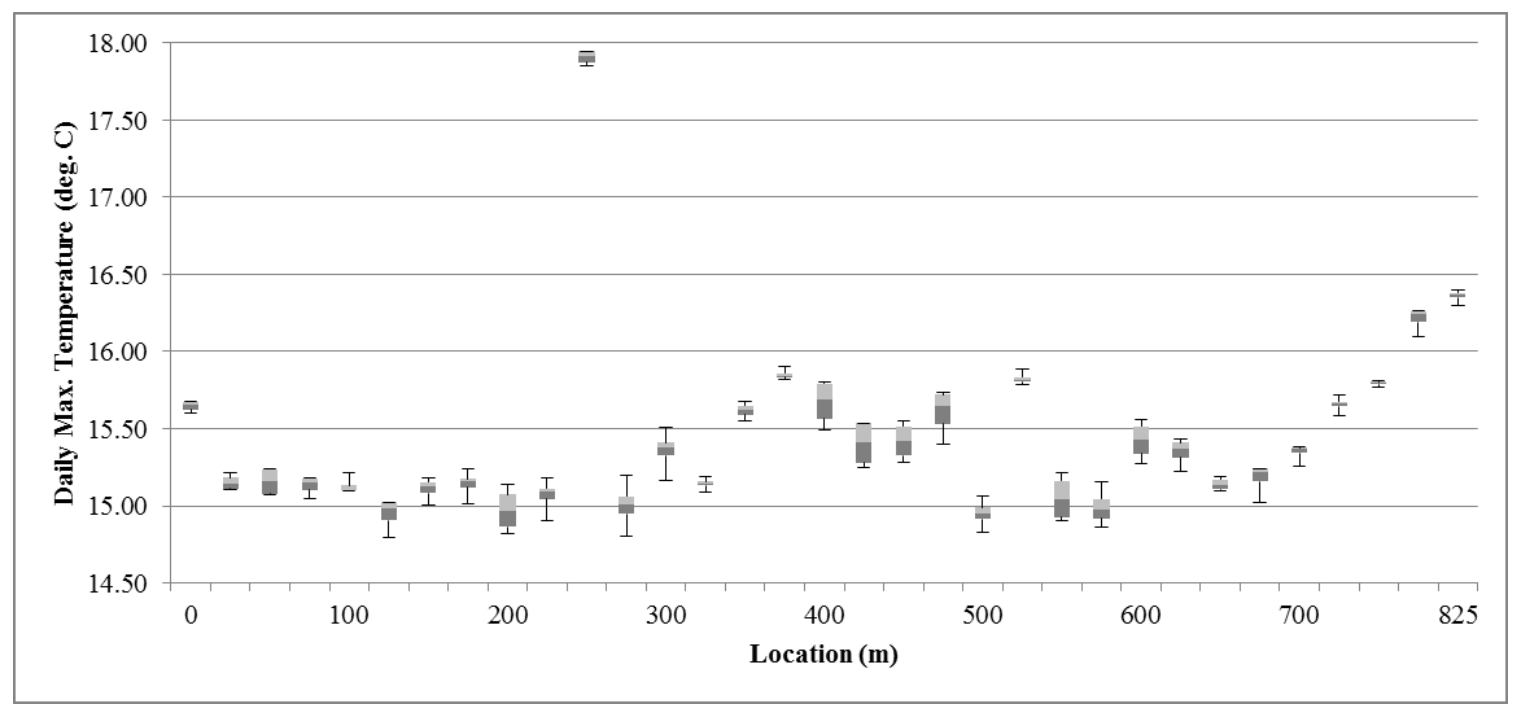

Figure 5. Minimum, maximum, $25^{\text {th }}$ and $75^{\text {th }}$ percentile, and median observed daily maximum temperatures (deg. C) per location on Little Creek.

Table 3. Mean daily stream temperature statistics per location on Little Creek.

\begin{tabular}{|lccccccccc|}
\hline Mean Daily & \multicolumn{9}{c}{ Location (m) } \\
Statistic (std. dev.) & 0 & 100 & 200 & 300 & 400 & 500 & 600 & 700 & 800 \\
\hline \multirow{2}{*}{ Maximum } & 15.64 & 15.11 & 14.97 & 15.34 & 15.67 & 15.43 & 15.42 & 15.36 & 16.21 \\
& $(.033)$ & $(.082)$ & $(.148)$ & $(.147)$ & $(.153)$ & $(.160)$ & $(.132)$ & $(.076)$ & $(.081)$ \\
Minimum & 14.18 & 14.09 & 13.95 & 13.73 & 14.25 & 14.37 & 14.48 & 14.68 & 14.76 \\
& $(.215)$ & $(.225)$ & $(.229)$ & $(.217)$ & $(.151)$ & $(.162)$ & $(.102)$ & $(.091)$ & $(.087)$ \\
Average & 14.82 & 14.54 & 14.4 & 14.42 & 14.57 & 14.7 & 14.77 & 15.01 & 15.23 \\
& $(.073)$ & $(.069)$ & $(.076)$ & $(.062)$ & $(.136)$ & $(.117)$ & $(.091)$ & $(.056)$ & $(.047)$ \\
\hline
\end{tabular}

\section{$\underline{\text { Hydrologic Processes }}$}

Streamflow dilution gaging from dye tracer measurements indicated that a net gain in flow occurred throughout the length of the study site with flow from the North Fork reach nearly doubling following the confluence of the South Fork (Table 4).

Downstream additions in streamflow were solely accounted for by tributary inflows indicating that gains from groundwater were non-existent. 


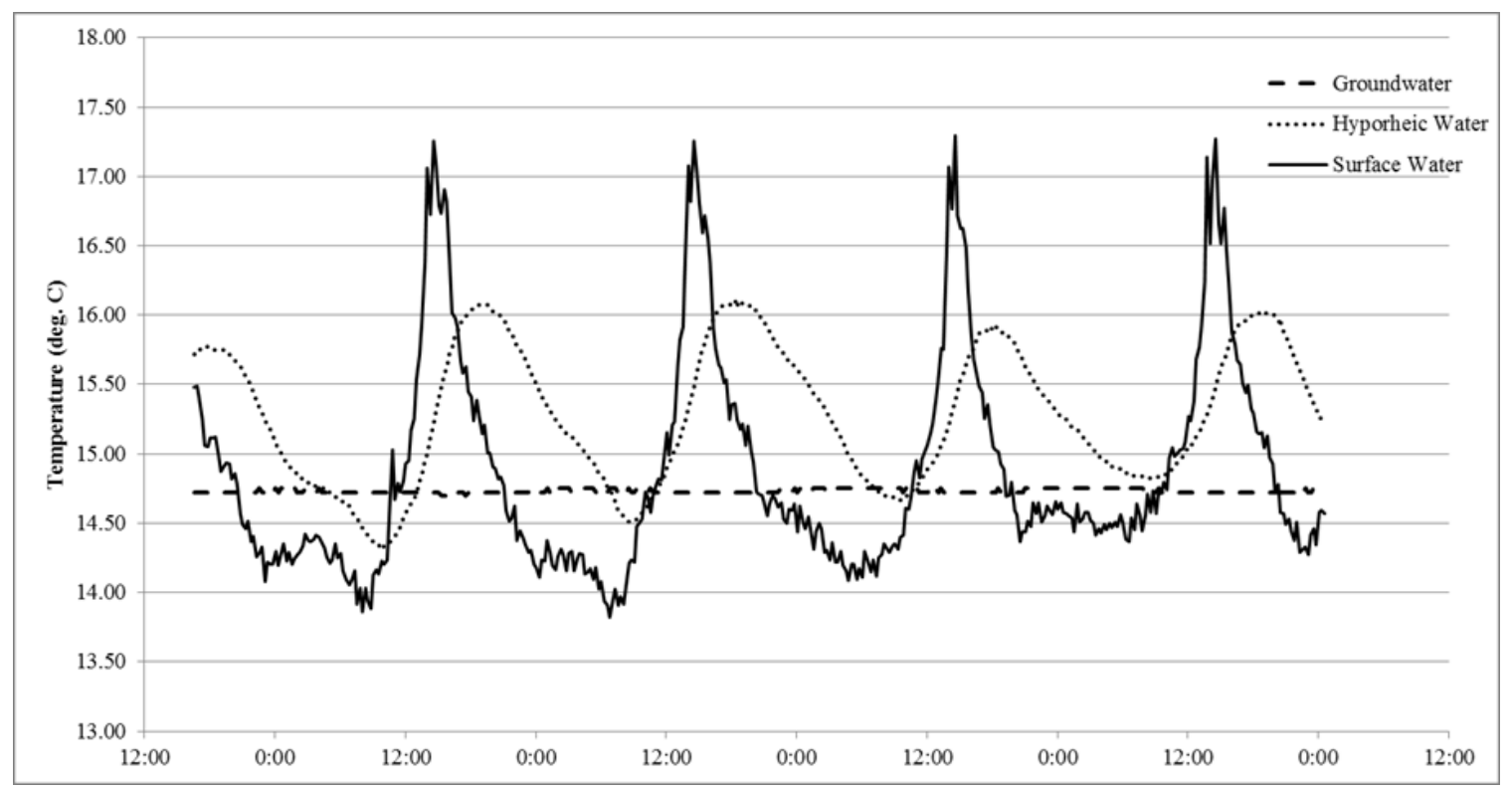

Figure 6. Observed surface, hyporheic, and groundwater temperatures at location $390 \mathrm{~m}$ on Little Creek.

These findings are consistent with observations made on similar streams occurring in mountainous regions with more incised, steeper channel gradients (Hewlett, 1982). OTIS-P modeling yielded higher hyporheic exchange rates and stream residence times in the North Fork reach compared to the Main Stem reach.

Table 4. Hydrologic measurements on Little Creek per study reach segment.

\begin{tabular}{|lccc|}
\hline $\begin{array}{l}\text { Study Reach Segment } \\
\text { and Inflows }\end{array}$ & $\mathrm{Q}\left(\mathrm{m}^{3} \mathrm{~s}^{-1}\right)$ & $\begin{array}{c}\text { Hyporheic Exchange } \\
\text { Rate }\left(\mathrm{m}^{3} \mathrm{~s}^{-1} \mathrm{~m}^{-1}\right)\end{array}$ & $\begin{array}{r}\text { Ave. Residence Time } \\
(\mathrm{hrs} . / 100 \mathrm{~m})\end{array}$ \\
\hline North Fork $(0-488 \mathrm{~m})$ & $0.0027^{\mathrm{a}}$ & $7.300 \mathrm{E}-04$ & 1.11 \\
South Fork Tributary & $0.0020^{\mathrm{a}}$ & - & - \\
Main Stem (488-680m) & 0.0047 & $5.300 \mathrm{E}-04$ & - \\
Residential Drainage & $0.0009^{\mathrm{a}}$ & - & 0.86 \\
Main Stem $(680-835 \mathrm{~m})$ & $0.0056^{\mathrm{a}}$ & $5.300 \mathrm{E}-04$ & 0.86 \\
\hline
\end{tabular}

${ }^{a}$ measured discharge 
Steeper channel gradients, observed in the North Fork reach, often provide the energy for more downwelling and subsurface-surface water mixing and therefore increasing average residence times.

\section{Heat Budget Modeling}

Relative influences of heat budget variables on downstream temperature change were found to vary between distances which heat transfer and subsequent temperature changes occurred. Individual heat budget variables also varied between a net heating or cooling effect on stream temperature change.

Observed and modeled stream temperatures at location $100 \mathrm{~m}$ yielded some of the lowest daily maximum temperatures within the study site (Figure 7) and likely explains how all heat budget components associated with temperature change provided a net cooling effect over the first $100 \mathrm{~m}$ of the study site based on Pearson correlations (Table 5). While correlation coefficients of net radiation (Nr), latent heat exchange (Qe), and sensible heat flux (Qh) were closer to zero (indicating no relationship), the negative coefficients likely indicate that the magnitude of individual heat fluxes decreased or were less than other locations in the study site which resulted in a net decrease in temperature throughout the majority of the study period (Figure 8). Latent heat exchange (Qe) and hyporheic flux (Qhyp) were found to be the most statistically relevant variables $(\alpha<.05)$ which remains consistent with the higher observed hyporheic exchange rate along the North Fork reach. 


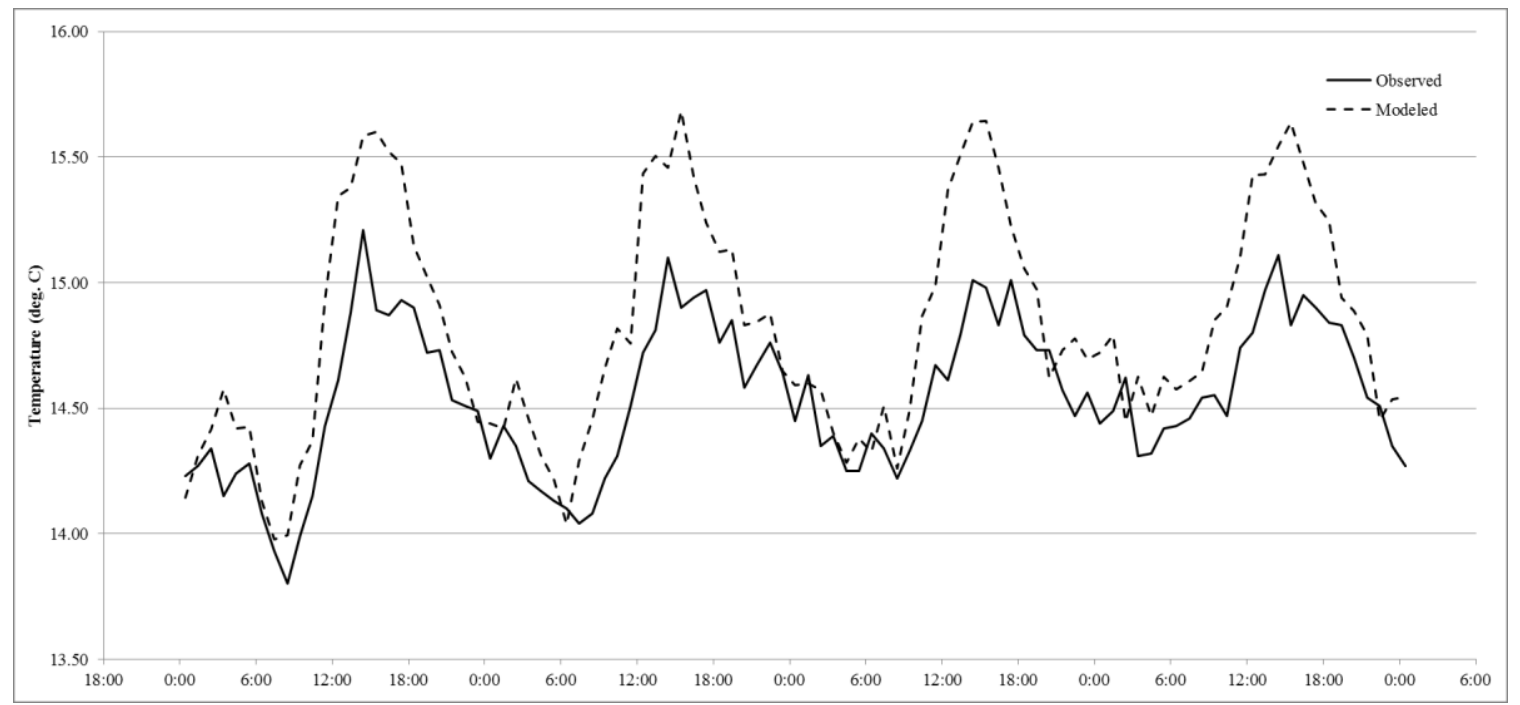

Figure 7. Observed and modeled stream temperatures on Little Creek at location $100 \mathrm{~m}$ from August 20-25, 2014.

Trends in heat budget variables and their relative heating or cooling influence on stream temperatures began to diverge from the net cooling trend observed over the first $100 \mathrm{~m}$ as warming occurred over the first $300 \mathrm{~m}$ (Figure 9). Hyporheic flux (Qhyp) and latent heat exchange (Qe) were found to be statistically relevant variables $(\alpha<.05)$ with net radiation $(\mathrm{Nr})$ becoming more significant and exhibiting a net warming effect, likely due to decreases in stream shading between locations 100 and $300 \mathrm{~m}$ (Table 6).

Table 5. Regression analysis results, comparing heat budget components with hourly stream temperature change, on Little Creek over first $100 \mathrm{~m}$.

\begin{tabular}{|lccccc|}
\hline $\begin{array}{l}\text { Heat Budget } \\
\text { Variable }\end{array}$ & $\begin{array}{c}\text { Pearson } \\
\text { Correlation }\end{array}$ & $\beta$ & $\mathrm{SE}$ & $\mathrm{t}$ & $\mathrm{p}$ \\
\hline constant & - & -0.072 & 0.037 & -1.973 & 0.051 \\
$\mathrm{Nr}$ & -0.295 & 0.000 & 0.000 & -1.092 & 0.277 \\
$\mathrm{Qc}$ & -0.583 & - & - & - & - \\
Qe & -0.261 & -0.011 & 0.004 & -2.734 & 0.007 \\
Qh & -0.178 & -0.003 & 0.004 & -0.756 & 0.452 \\
Qhyp & -0.614 & -0.012 & 0.001 & -8.263 & 0.000 \\
\hline
\end{tabular}




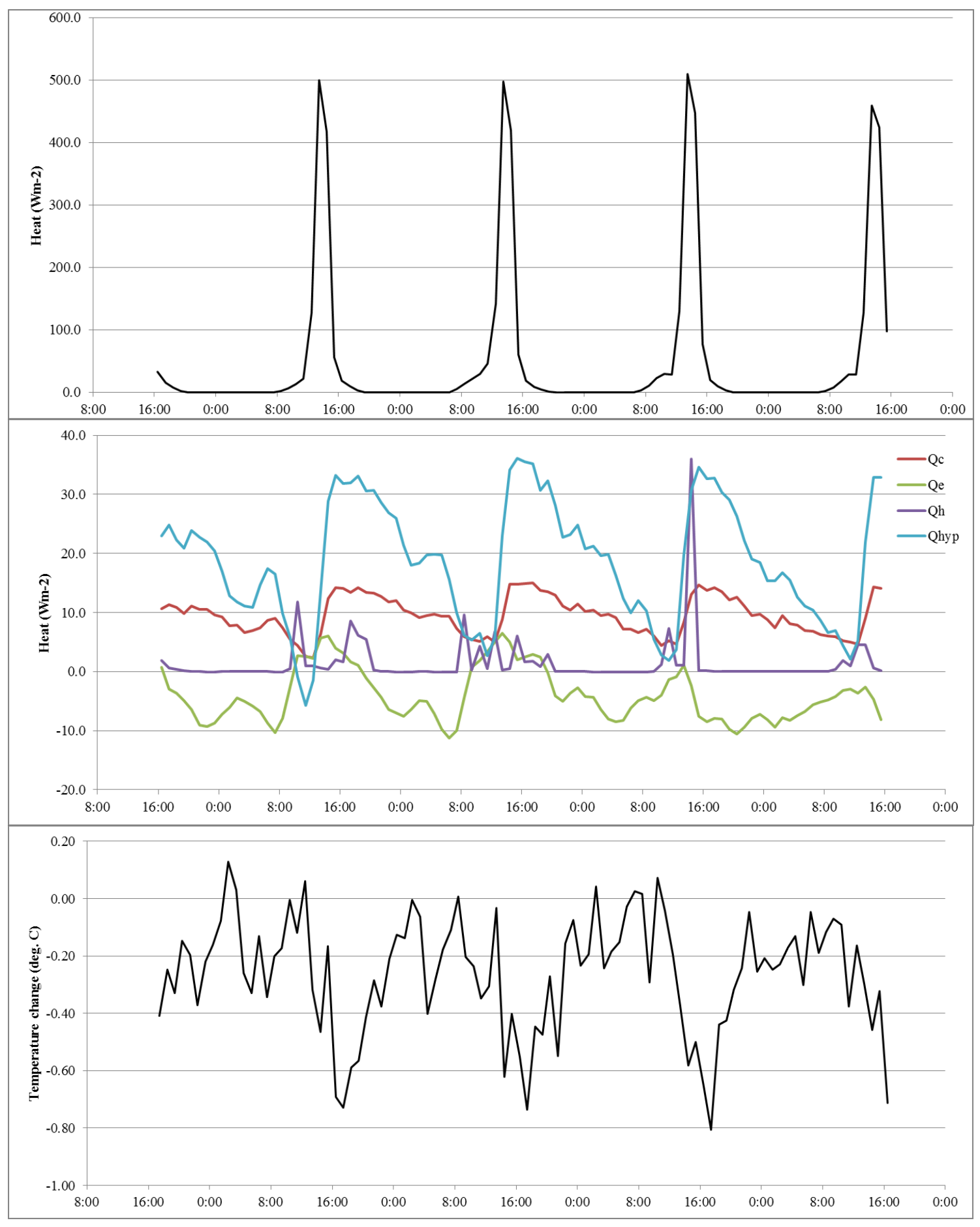

Figure 8. Plots of net radiation (top), heat budget components (middle), and stream temperature change (bottom) on Little Creek at location 100 m from August 20-25, 2014. 


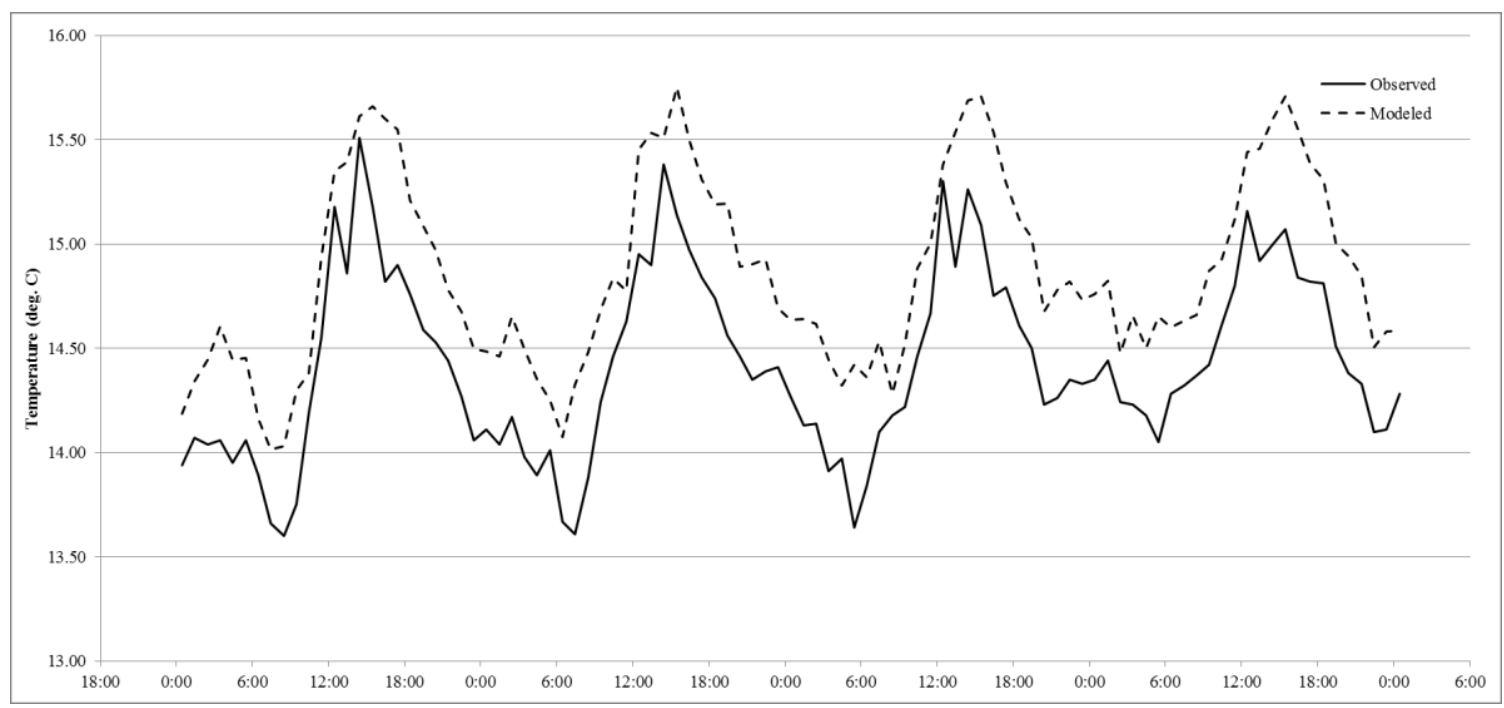

Figure 9. Observed and modeled stream temperatures on Little Creek at location $300 \mathrm{~m}$ from August 20-25, 2014.

While average net radiation was found to be less than average net radiation over the first $100 \mathrm{~m}$ and averages for all other heat budget variables were found to be similar, further stream temperature cooling between locations 100 and $200 \mathrm{~m}$ (Table 3) indicates that enough heat was added to the system between locations 200 and $300 \mathrm{~m}$ to offset this cooling effect and create a net warming effect by the time water reached location $300 \mathrm{~m}$ (Figure 10).

Table 6. Regression analysis results, comparing heat budget components with hourly stream temperature change, on Little Creek over first $300 \mathrm{~m}$.

\begin{tabular}{|lccccc|}
\hline $\begin{array}{l}\text { Heat Budget } \\
\text { Variable }\end{array}$ & $\begin{array}{c}\text { Pearson } \\
\text { Correlation }\end{array}$ & $\beta$ & SE & $\mathrm{t}$ & $\mathrm{p}$ \\
\hline constant & - & 0.516 & 0.061 & 8.481 & 0.000 \\
$\mathrm{Nr}$ & 0.162 & 0.001 & 0.000 & 1.871 & 0.064 \\
$\mathrm{Qc}$ & -0.837 & - & - & - & - \\
$\mathrm{Qe}$ & 0.249 & 0.020 & 0.006 & 3.452 & 0.001 \\
Qh & 0.055 & 0.002 & 0.004 & 0.402 & 0.689 \\
Qhyp & -0.837 & -0.041 & 0.002 & -17.892 & 0.000 \\
\hline
\end{tabular}



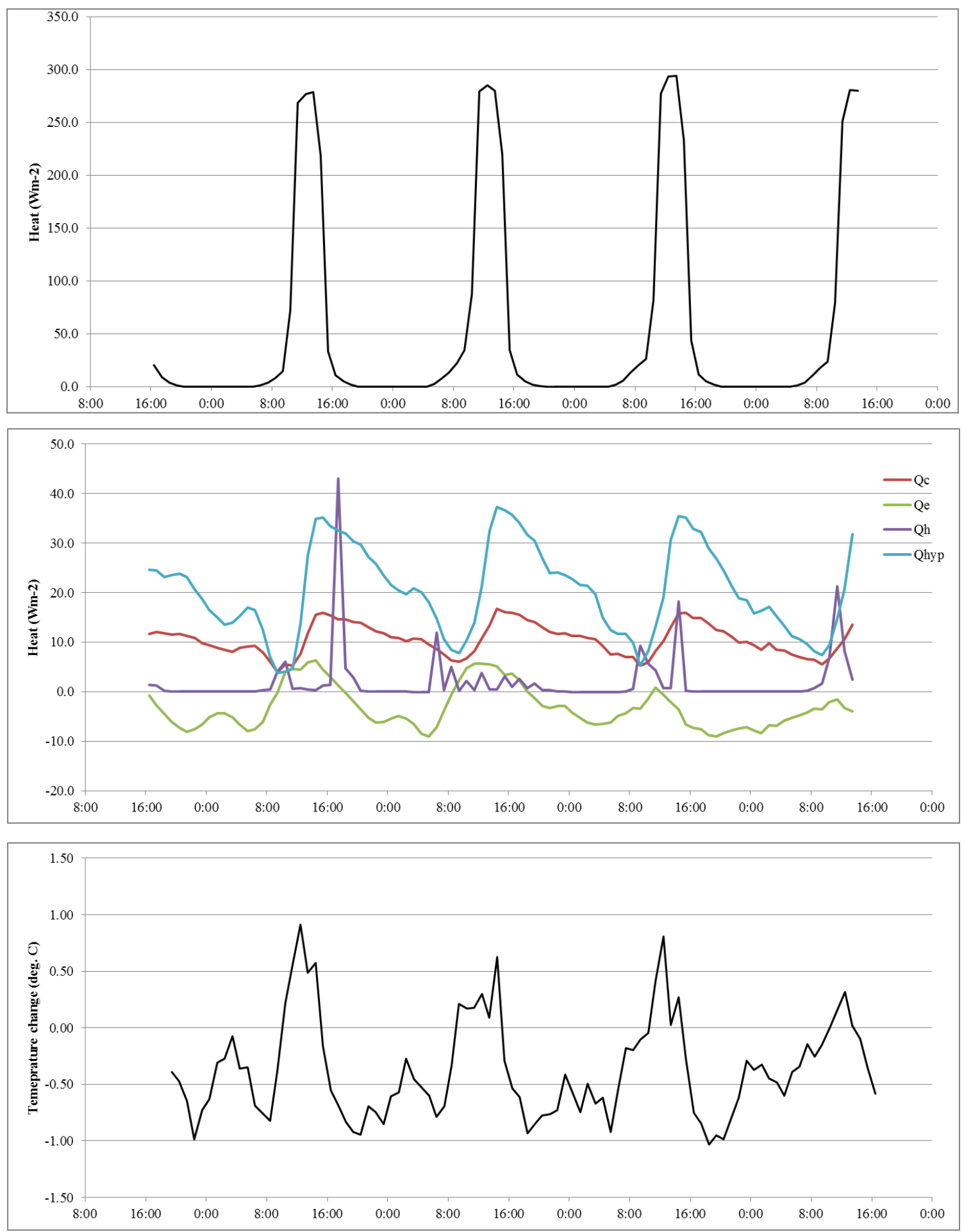

Figure 10. Plots of net radiation (top), heat budget components (middle), and stream temperature change (bottom) on Little Creek at location 300 m from August 20-25, 2014. 


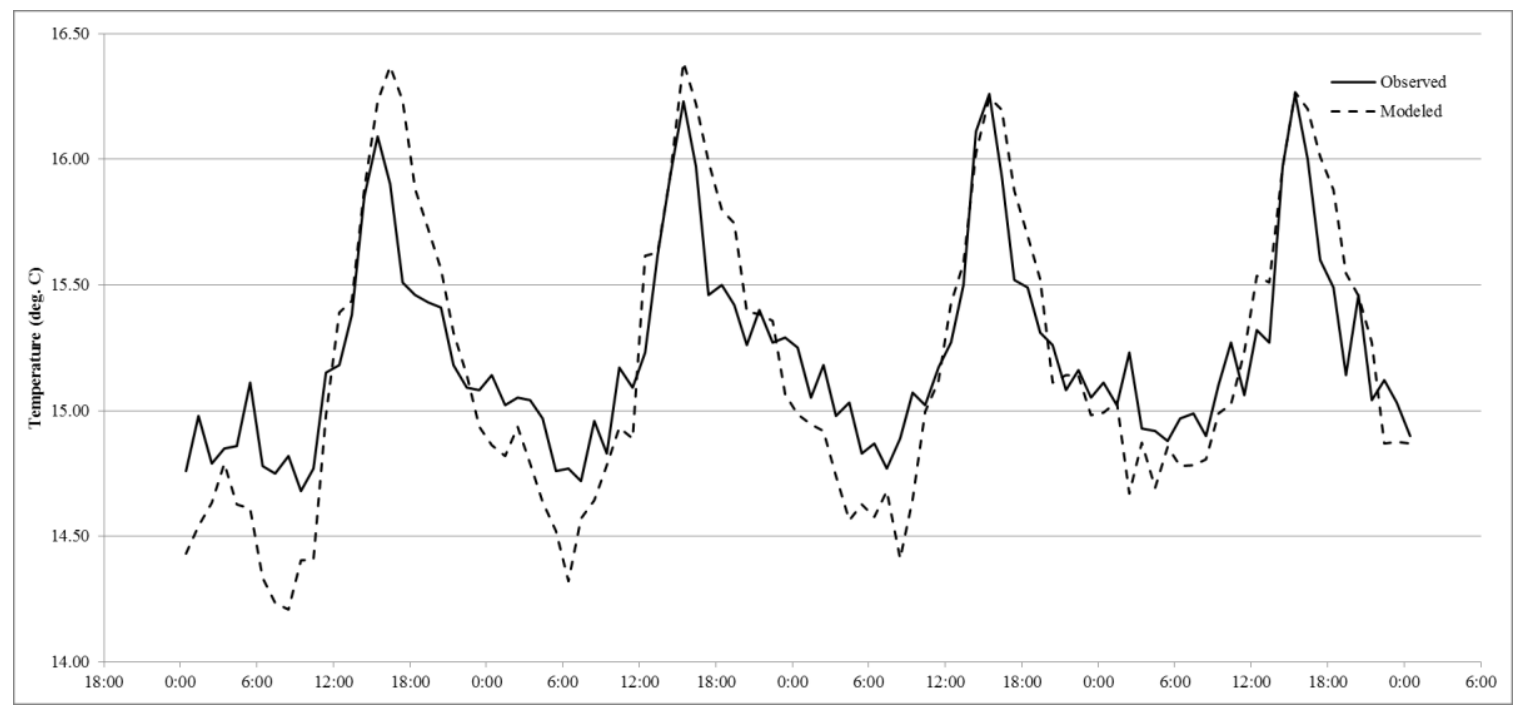

Figure 11. Observed and modeled stream temperatures on Little Creek at location $800 \mathrm{~m}$ from August 20-25, 2014.

An additional net warming effect between locations $300 \mathrm{~m}$ and $800 \mathrm{~m}$ lead to warmer daily maximum and average stream temperatures observed at location $800 \mathrm{~m}$ (Figure 11). Hyporheic flux (Qhyp) and streambed conduction (Qc) were found to exhibit negative correlations with temperature change while the positive correlation of net radiation $(\mathrm{Nr})$ became stronger compared to correlations observed over the first 100 and $300 \mathrm{~m}$ (Table 7). Net radiation, hyporheic flux, and latent heat exchange were found to be highly significant $(\alpha<.05)$.

Table 7. Regression analysis results, comparing heat budget components with hourly stream temperature change, on Little Creek over $800 \mathrm{~m}$.

\begin{tabular}{|lccccc|}
\hline $\begin{array}{l}\text { Heat Budget } \\
\text { Variable }\end{array}$ & $\begin{array}{c}\text { Pearson } \\
\text { Correlation }\end{array}$ & $\beta$ & $\mathrm{SE}$ & $\mathrm{t}$ & $\mathrm{p}$ \\
\hline constant & - & 1.823 & 0.110 & 16.571 & 0.000 \\
$\mathrm{Nr}$ & 0.411 & 0.004 & 0.001 & 6.510 & 0.000 \\
Qc & -0.694 & - & - & - & - \\
Qe & 0.271 & 0.039 & 0.010 & 4.051 & 0.000 \\
Qh & 0.171 & -0.005 & 0.005 & -0.992 & 0.324 \\
Qhyp & -0.769 & -0.088 & 0.004 & -19.674 & 0.000 \\
\hline
\end{tabular}




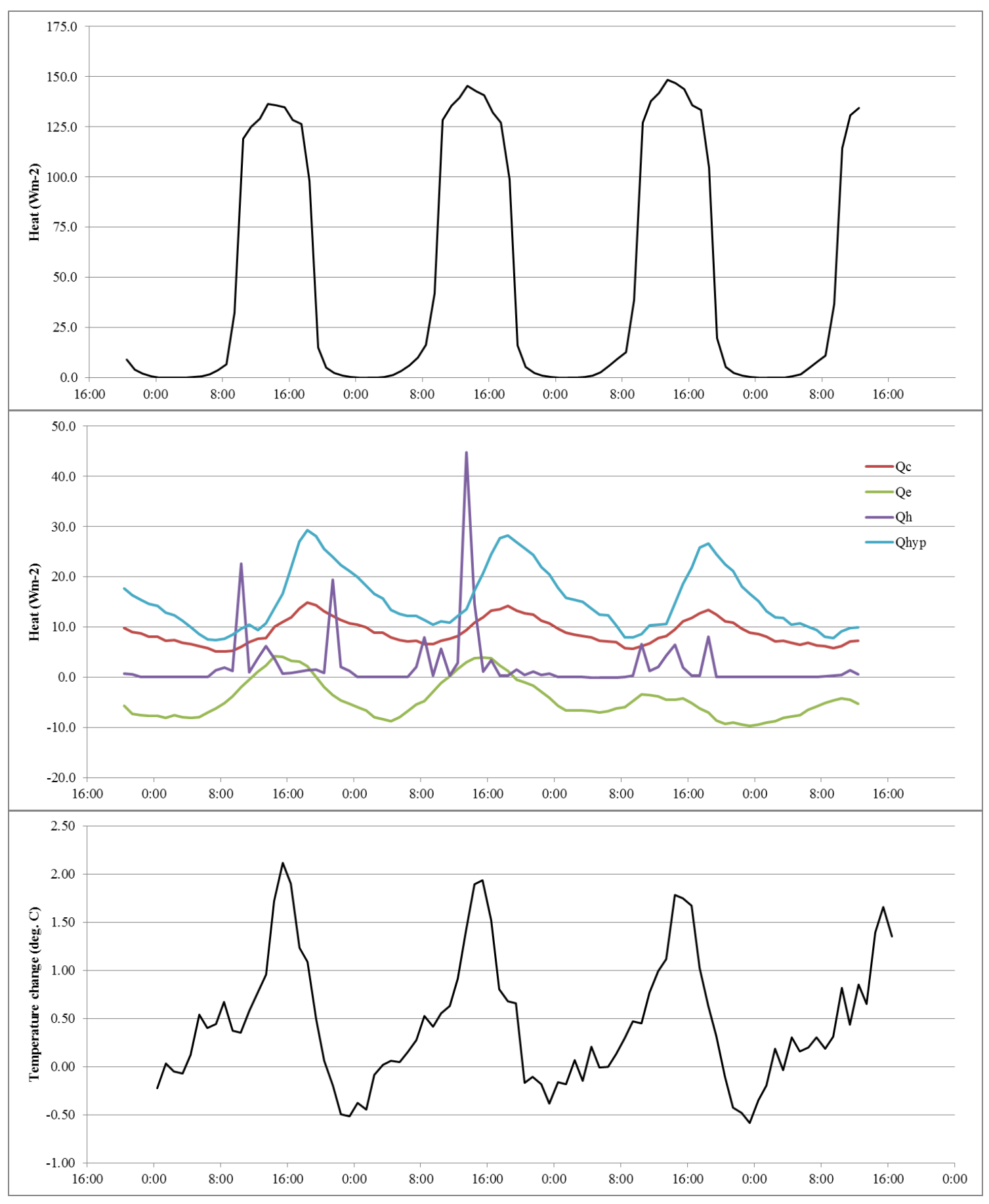

Figure 12. Plots of net radiation (top), heat budget components (middle), and stream temperature change (bottom) on Little Creek at location 800 m from August 20-25, 2014. 
The weaker relationship between hyporheic heat exchange and stream temperature in the main stem (lower segment) are a departure from the significant influences of hyporheic flux on downstream temperature change within the North Fork reach (upper segment). Lower measured hyporheic exchange rates along the main stem reach, along with reductions in canopy coverage as the occurrence of streamside hardwood tree species increases along the main stem, may explain the predominant influence of net radiation on downstream heating as exhibited by daily maximum stream temperature trends at location $800 \mathrm{~m}$ (Figure 12).

\section{Physical Characteristics and Daily Maximum Temperatures}

Aspect ratio (stream width to depth) and percent shading were the only two variables to be statistically significant $(\alpha<.05)$ from regression analysis of physical channel characteristics to daily maximum daily temperatures (Table 8). Correlation coefficients indicate that higher aspect ratios (greater width to depth) and lower stream shading values corresponded to greater daily maximum temperatures throughout the study site. Channel reaches with higher aspect ratios are generally associated with shallow gravel bars and riffles where more downwelling, hyphoreic exchange, and localized stream temperature cooling potentially occurs. Reductions in percent shading, and subsequent increases in net radiation, are consistent with results from similar studies and help explain stream heating not only over $100 \mathrm{~m}$ distance steps but possibly over the entire $825 \mathrm{~m}$ of the study site. 
Table 8. Regression analysis results, comparing physical channel variables and mean daily maximum stream temperature, on Little Creek.

\begin{tabular}{|lccccc|}
\hline Physical Variable & $\begin{array}{c}\text { Pearson } \\
\text { Correlation }\end{array}$ & $\beta$ & SE & $\mathrm{t}$ & $\mathrm{p}$ \\
\hline constant & - & 19.119 & 1.845 & 10.362 & 0.000 \\
Width & -0.102 & -0.058 & 0.155 & -0.377 & 0.709 \\
Depth & -0.207 & 0.646 & 1.641 & 0.394 & 0.697 \\
Aspect ratio & 0.633 & 0.008 & 0.002 & 3.920 & 0.001 \\
Percent shading & -0.419 & -0.047 & 0.020 & -2.421 & 0.023 \\
Floodprone width & -0.231 & -0.149 & 0.123 & -1.218 & 0.234 \\
Bankfull width & -0.084 & 0.241 & 0.224 & 1.079 & 0.291 \\
Entrenchment ratio & -0.092 & 0.349 & 0.312 & 1.116 & 0.275 \\
\hline
\end{tabular}

\section{Modeled Effects from Shade Reduction}

Modeled stream temperatures at locations $300 \mathrm{~m}$ and $800 \mathrm{~m}$ responded noticeably to both $50 \%$ and $100 \%$ shade reductions occurring over the first $300 \mathrm{~m}$ with the increased heat having less of an effect as water moves downstream (Table 9). Daily maximum temperatures at location $300 \mathrm{~m}$ increased by an average of 1.76 and $2.16 \mathrm{deg}$. $\mathrm{C}$ for the $50 \%$ and $100 \%$ shade reduction scenarios respectively, while daily maximum temperatures at location $300 \mathrm{~m}$ increased by an average of 1.54 and $1.62 \mathrm{deg}$. C for the $50 \%$ and $100 \%$ shade reduction scenarios respectively. Mean daily minimum temperatures were found to decrease under both shade reduction scenarios at both locations but only deviated by a maximum magnitude of $0.50 \mathrm{deg}$. C. Mean daily average temperatures were found to increase under both scenarios at both locations with only modest deviations of $0.31 \mathrm{deg}$. $\mathrm{C}$ or less. 
Results could not conclude what distance beyond $825 \mathrm{~m}$ would be affected by the additional heat, but do suggest that the additional upstream heat, coupled with localized cooling processes which naturally occur between various reaches, began to dissipate with increased distance downstream of the heat source.

Table 9. Modeled results of shade reduction scenarios on Little Creek at locations $300 \mathrm{~m}$ and $800 \mathrm{~m}$. Values for results at the distances and deviation from current are in deg. $\mathrm{C}$

\begin{tabular}{|ll|cc|cc|}
\hline $\begin{array}{l}\text { Mean Daily } \\
\text { Statistic }\end{array}$ & \multicolumn{1}{c}{ Shading scenario } & $300 \mathrm{~m}$ & $\begin{array}{c}\text { deviation } \\
\text { from current }\end{array}$ & $800 \mathrm{~m}$ & $\begin{array}{c}\text { deviation } \\
\text { from current }\end{array}$ \\
\hline \multirow{3}{*}{ Maximum } & Current & 15.34 & & 16.21 & \\
& $50 \%$ reduction & 17.10 & 1.76 & 17.75 & 1.54 \\
& $100 \%$ reduction & 17.50 & 2.16 & 17.83 & 1.62 \\
\hline \multirow{3}{*}{ Minimum } & Current & 13.73 & & 14.76 & \\
& 50\% reduction & 13.42 & -0.31 & 14.56 & -0.20 \\
& $100 \%$ reduction & 13.23 & -0.50 & 14.60 & -0.16 \\
\hline \multirow{3}{*}{ Average } & Current & 14.43 & & 15.23 & \\
& 50\% reduction & 14.52 & 0.09 & 15.51 & 0.28 \\
& $100 \%$ reduction & 14.63 & 0.20 & 15.54 & 0.31 \\
\hline
\end{tabular}

\section{Modeled Effects from Groundwater Inflows}

Modeled increases in groundwater inflows resulted in a net cooling effect of modeled temperatures at both $300 \mathrm{~m}$ and $800 \mathrm{~m}$ locations (Tables 10, 11). Deviations of mean daily maximum temperatures at location $300 \mathrm{~m}$ ranged from $-0.27 \mathrm{deg}$. C for a $10 \%$ increase and $-1.00 \mathrm{deg}$. $\mathrm{C}$ for a $50 \%$ increase in groundwater inflow. Decreases in mean daily maximum temperatures at $800 \mathrm{~m}$ ranged from $-0.21 \mathrm{deg}$. $\mathrm{C}$ to $-0.78 \mathrm{deg}$. $\mathrm{C}$ for $10 \%$ and $50 \%$ increases in groundwater inflow respectively. The magnitude of the net cooling 
effect only had a modest increase at location $300 \mathrm{~m}$ from the $50 \%$ to $100 \%$ shade reductions scenarios while magnitude effect increased at location $800 \mathrm{~m}$ from $-0.78 \mathrm{deg}$. C to -0.92 deg. $\mathrm{C}$ for the $50 \%$ and $100 \%$ shade reduction scenarios respectively. Modeled results indicate that potential groundwater increases from reduced evapotranspiration following near stream vegetation removal have the potential to partially mitigate the effects of additional heat added to the system.

Table 10. Modeled results from groundwater inflows for $50 \%$ and $100 \%$ shade reduction scenarios on Little Creek at location $300 \mathrm{~m}$.

\begin{tabular}{|ll|cc|cc|}
\hline $\begin{array}{l}\text { Mean Daily } \\
\text { Statistic }\end{array}$ & \multicolumn{1}{c}{ Groundwater scenario } & $\begin{array}{c}50 \% \text { shade } \\
\text { reduction }\end{array}$ & $\begin{array}{c}\text { deviation from no } \\
\text { groundwater }\end{array}$ & $\begin{array}{c}100 \% \text { shade } \\
\text { reduction }\end{array}$ & $\begin{array}{c}\text { deviation from no } \\
\text { groundwater }\end{array}$ \\
\hline \multirow{4}{*}{ Maximum } & $10 \%$ increase & 16.89 & -0.21 & 17.25 & -0.25 \\
& $20 \%$ increase & 16.71 & -0.39 & 17.04 & -0.46 \\
& $30 \%$ increase & 16.56 & -0.54 & 16.87 & -0.63 \\
\hline \multirow{4}{*}{ Minimum } & $50 \%$ increase & 16.32 & -0.78 & 16.58 & -0.92 \\
& $10 \%$ increase & 13.54 & 0.12 & 13.37 & 0.14 \\
& $20 \%$ increase & 13.64 & 0.22 & 13.48 & 0.25 \\
\hline \multirow{4}{*}{ Average } & $30 \%$ increase & 13.73 & 0.31 & 13.58 & 0.35 \\
& $50 \%$ increase & 13.86 & 0.44 & 13.74 & 0.51 \\
\hline & $10 \%$ increase & 14.54 & 0.02 & 14.64 & 0.01 \\
& $20 \%$ increase & 14.56 & 0.04 & 14.65 & 0.02 \\
\hline
\end{tabular}

Table 11. Modeled results from groundwater inflows for 50\% and 100\% shade reduction scenarios on Little Creek at location $800 \mathrm{~m}$.

\begin{tabular}{|ll|cc|cc|}
\hline $\begin{array}{l}\text { Mean Daily } \\
\text { Statistic }\end{array}$ & \multicolumn{1}{c}{ Groundwater scenario } & $\begin{array}{c}\text { 50\% shade } \\
\text { reduction }\end{array}$ & $\begin{array}{c}\text { deviation fromno } \\
\text { groundwater } \\
\text { inflow }\end{array}$ & $\begin{array}{c}\text { 100\% shade } \\
\text { reduction }\end{array}$ & $\begin{array}{c}\text { deviation from no } \\
\text { groundwater } \\
\text { inflow }\end{array}$ \\
\hline \multirow{3}{*}{ Maximum } & $10 \%$ increase & 17.48 & -0.27 & 17.55 & -0.28 \\
& $20 \%$ increase & 17.25 & -0.50 & 17.32 & -0.51 \\
& $30 \%$ increase & 17.06 & -0.69 & 17.12 & -0.71 \\
\hline \multirow{3}{*}{ Minimum } & $50 \%$ increase & 16.75 & -1.00 & 16.80 & -1.03 \\
\hline & $10 \%$ increase & 14.57 & 0.01 & 14.61 & 0.01 \\
& $20 \%$ increase & 14.59 & 0.03 & 14.63 & 0.03 \\
Average & $30 \%$ increase & 14.60 & 0.04 & 14.63 & 0.03 \\
& $50 \%$ increase & 14.62 & 0.06 & 14.65 & 0.05 \\
\hline & $10 \%$ increase & 15.44 & -0.07 & 15.28 & -0.26 \\
& $20 \%$ increase & 15.39 & -0.12 & 15.36 & -0.18 \\
\hline
\end{tabular}




\section{Scotts Creek}

Stream temperatures during the August 12 to 17 study period of 2015 yielded mostly warmer temperatures with differing trends in heating and cooling compared to Little Creek. Diurnal stream temperatures fluctuations varied from approximately 1 and 4 deg. $\mathrm{C}$ among locations throughout the study site with mean daily maximum temperature of 17.34 deg. $\mathrm{C}$ and mean daily minimum temperature of $15.30 \mathrm{deg}$. $\mathrm{C}$ for the study period. Mean daily average temperature for the entire study site was $16.32 \mathrm{deg}$. C. Temporal patterns in stream temperatures were found to be consistent with expected diurnal fluctuations observed in most systems with daily maximum temperature for a given location occurring later in the day between 16:00 and 17:00, which lagged behind peak daily maximum net radiation for that location. Daily maximum and minimum temperatures however were found to vary spatially (Table 12; Figure 13).

Table 12. Mean daily stream temperature statistics per location on Scotts Creek.

\begin{tabular}{|lcccccccccccccccccc|}
\hline Temperature & & & & & & & & \multicolumn{1}{c}{ Location (m) } & & & & & \\
statistic (std. dev.) & 0 & 25 & 50 & 75 & 100 & 125 & 150 & 175 & 200 & 625 & 650 & 675 & 700 & 725 & 750 & 775 & 800 & 825 \\
\hline Mean Daily & 17.8 & 16.33 & 17.31 & 16.52 & 16.12 & 18.67 & 17.65 & 17.31 & 18.25 & 18.28 & 16.65 & 17.86 & 17.25 & 17.68 & 17.01 & 16.8 & 16.66 & 17.95 \\
Maximum & $(.700)$ & $(.149)$ & $(.626)$ & $(.244)$ & $(.240)$ & $(.692)$ & $(.571)$ & $(.626)$ & $(.412)$ & $(.871)$ & $(.192)$ & $(.290)$ & $(.152)$ & $(.369)$ & $(.208)$ & $(.305)$ & $(.203)$ & $(.412)$ \\
Mean Daily & 15.22 & 15.05 & 15.01 & 14.86 & 15.01 & 14.87 & 15.23 & 15.02 & 15.32 & 15.23 & 15.77 & 15.42 & 15.51 & 15.39 & 15.94 & 15.54 & 15.51 & 15.52 \\
Minimum & $(.391)$ & $(.363)$ & $(.345)$ & $(.383)$ & $(.416)$ & $(.394)$ & $(.336)$ & $(.345)$ & $(.304)$ & $(.344)$ & $(.308)$ & $(.244)$ & $(.286)$ & $(.331)$ & $(.228)$ & $(.238)$ & $(.222)$ & $(.265)$ \\
Mean Daily & 16.5 & 15.61 & 16.24 & 15.74 & 15.46 & 16.42 & 16.56 & 16.24 & 16.64 & 16.76 & 16.57 & 16.54 & 16.48 & 16.61 & 16.55 & 16.34 & 16.16 & 16.58 \\
Average & $(.376)$ & $(.282)$ & $(.346)$ & $(.317)$ & $(.262)$ & $(.407)$ & $(.337)$ & $(.346)$ & $(.293)$ & $(.420)$ & $(.129)$ & $(.232)$ & $(.191)$ & $(.263)$ & $(.233)$ & $(.229)$ & $(.205)$ & $(.287)$ \\
\hline
\end{tabular}




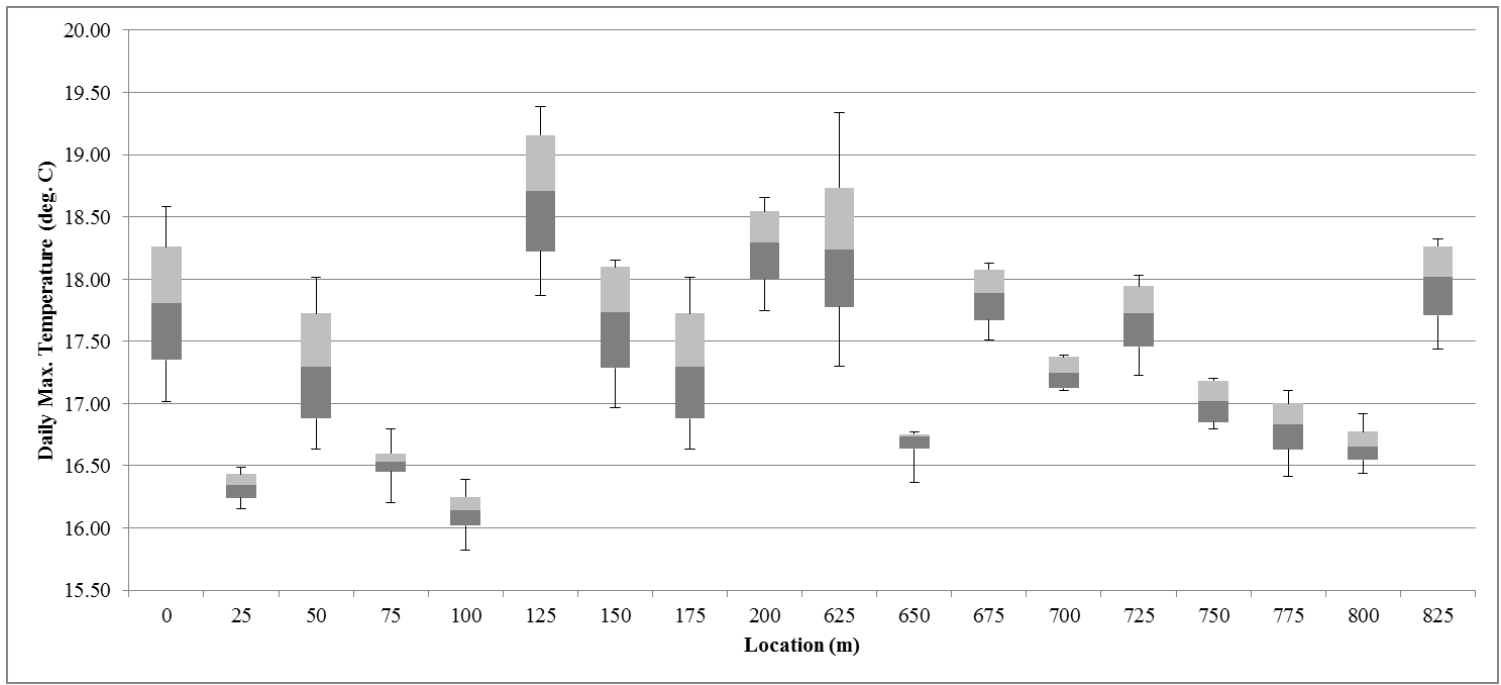

Figure 13. Minimum, maximum, $25^{\text {th }}$ and $75^{\text {th }}$ percentile, and median observed daily maximum stream temperatures (deg. C) per location on Scotts Creek.

For example daily maximum temperature of $16.52 \mathrm{deg}$. C was measured at location $75 \mathrm{~m}$ while 18.67 deg. C was measured at location 125 m (Figure 13). Variable heating and cooling trends occurred between all locations as water moved downstream with no discernible net heating or cooling effect occurring over the entire $825 \mathrm{~m}$. Average hyporheic temperatures were found to be less than surface water temperatures throughout the study site with average hyporheic temperatures of $15.85 \mathrm{deg}$. $\mathrm{C}$ in the upper reach (0$200 \mathrm{~m})$ and $16.62 \mathrm{deg} . \mathrm{C}$ in the lower reach $(625-825 \mathrm{~m})$.

\section{$\underline{\text { Hydrologic Processes }}$}

Streamflow dilution gaging from dye tracer measurements indicated that a net gain in flow (Table 13) was found to be negligible $\left(<0.001 \mathrm{~m}^{3} \mathrm{~s}^{-1}\right)$ and likely fell within the expected accuracy of the methods used to compute streamflow for the study. It was therefore determined that any groundwater inflows would also be negligible and were 
excluded from heat budget model computations. OTIS-P modeling yielded higher hyporheic exchange rates but lower stream residence times in the upper reach compared to the lower reach. Average residence time of approximately 17 days for the lower reach (Table 13) is likely attributed to the very low streamflow during the study period and presence of large pools and lower frequency of riffle sections.

Table 13. Hydrologic measurements on Scotts Creek per study reach segment.

\begin{tabular}{|lccc|}
\hline $\begin{array}{l}\text { Study Reach } \\
\text { Segment }\end{array}$ & $\mathrm{Q}\left(\mathrm{m}^{3} \mathrm{~s}^{-1}\right)$ & $\begin{array}{c}\text { Hyporheic Exchange } \\
\text { Rate }\left(\mathrm{m}^{3} \mathrm{~s}^{-1} \mathrm{~m}^{-1}\right)\end{array}$ & $\begin{array}{c}\text { Ave. Residence Time } \\
(\mathrm{hrs} . / 100 \mathrm{~m})\end{array}$ \\
\hline $\begin{array}{l}\text { Upper Reach }(0- \\
\begin{array}{l}\text { 200m) } \\
\text { Lower Reach (625- } \\
825 \mathrm{~m})\end{array}\end{array}$ & $8.36 \mathrm{E}-04$ & $4.20 \mathrm{E}-03$ & 61.24 \\
\hline
\end{tabular}

The relatively lower average residence time of approximately 2.5 days for the upper reach potentially explains the accumulation of streamflow downstream (assuming similar water velocities) due to an approximate seven-fold increase in the amount of time for that same water to move through the lower reach.

\section{$\underline{\text { Heat Budget Modeling }}$}

Relative influences of heat budget variables on downstream temperature change were found to vary between distances which heat transfer and subsequent temperature changes occurred. Individual heat budget variables also tended to vary depending on whether they provided a net heating or cooling effect on stream temperature change. 


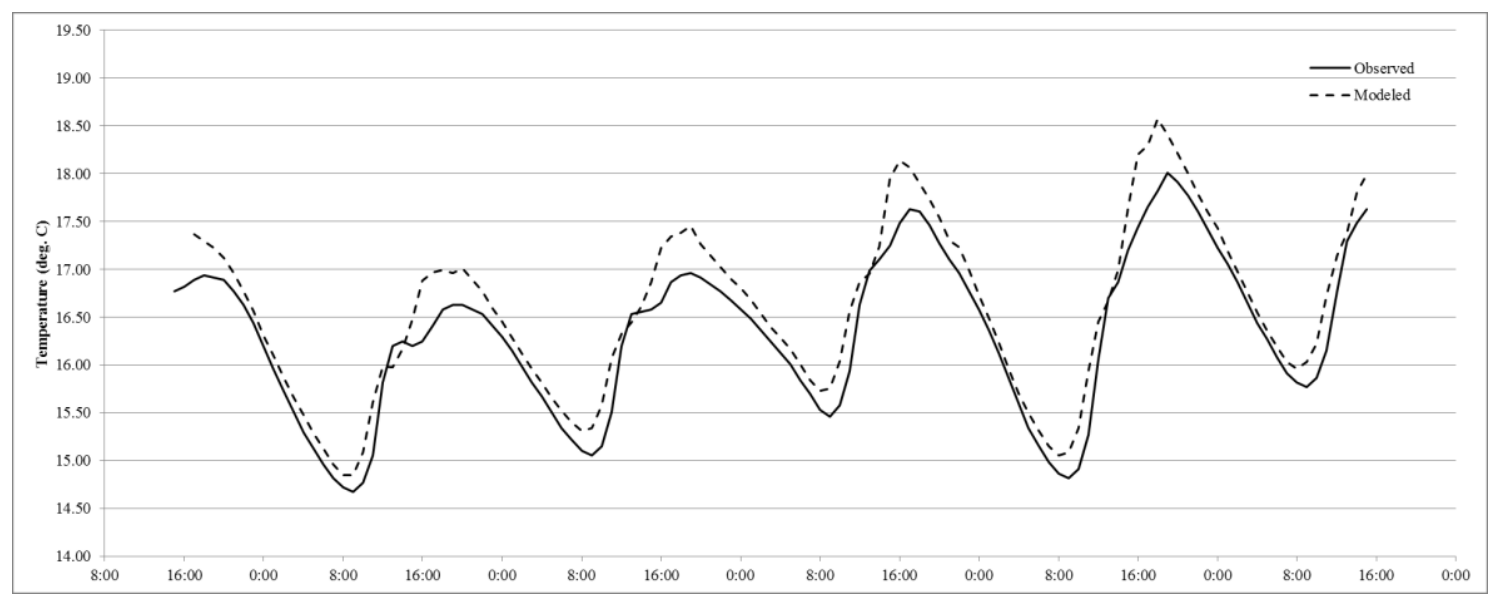

Figure 14. Observed and modeled stream temperatures on Scotts Creek at location $50 \mathrm{~m}$ from August 12-17, 2015.

Observed and modeled stream temperatures at location $50 \mathrm{~m}$ yielded a net cooling trend from location $0 \mathrm{~m}$ but with even more cooling from 0 to $25 \mathrm{~m}$ and warming from 25 to $50 \mathrm{~m}$ (Figures 14,15$)$. All heat budget components were found to have a statistically significant $(\alpha<.05)$ correlation with stream temperature change with the exception of sensible heat flux (Table 14). Net radiation (Nr) had the highest correlation in downstream heating over the $50 \mathrm{~m}$.

Table 14. Regression analysis results, comparing heat budget components with hourly stream temperature change, on Scotts Creek over first $50 \mathrm{~m}$.

\begin{tabular}{|lccccc|}
\hline $\begin{array}{l}\text { Heat Budget } \\
\text { Variable }\end{array}$ & $\begin{array}{c}\text { Pearson } \\
\text { Correlation }\end{array}$ & $\beta$ & $\mathrm{SE}$ & $\mathrm{t}$ & $\mathrm{p}$ \\
\hline constant & - & -0.471 & 0.032 & -14.709 & 0.000 \\
$\mathrm{Nr}$ & 0.922 & 0.004 & 0.000 & 10.238 & 0.000 \\
$\mathrm{Qc}$ & 0.237 & 0.127 & 0.035 & 3.633 & 0.000 \\
$\mathrm{Qe}$ & 0.592 & 0.004 & 0.001 & 4.16 & 0.000 \\
Qh & -0.086 & 0.002 & 0.003 & 0.613 & 0.541 \\
Qhyp & 0.296 & -0.005 & 0.001 & -3.271 & 0.001 \\
\hline
\end{tabular}




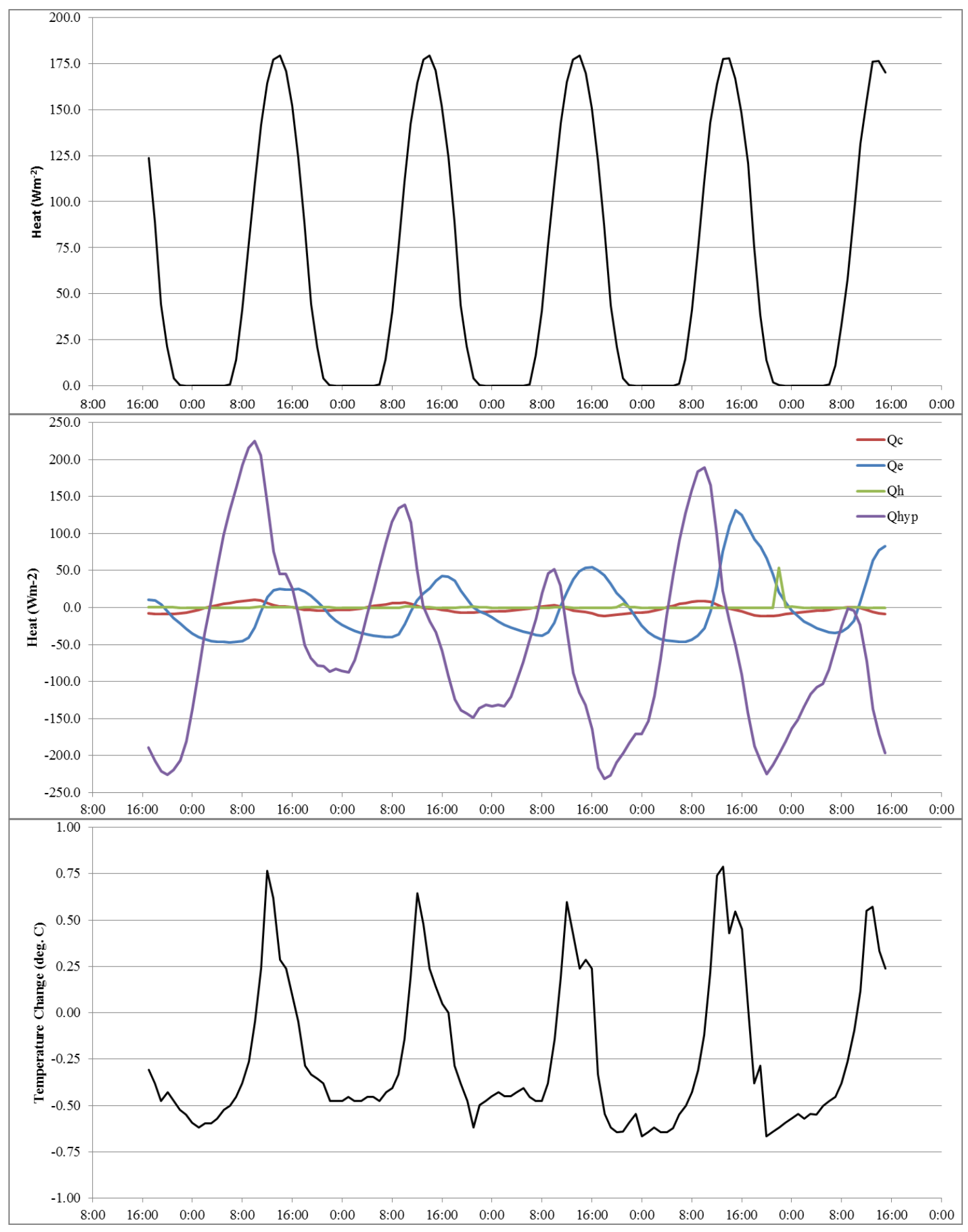

Figure 15. Plots of net radiation (top), heat budget components (middle), and stream temperature change (bottom) on Scotts Creek at location 50 m from August 12-17, 2015. 


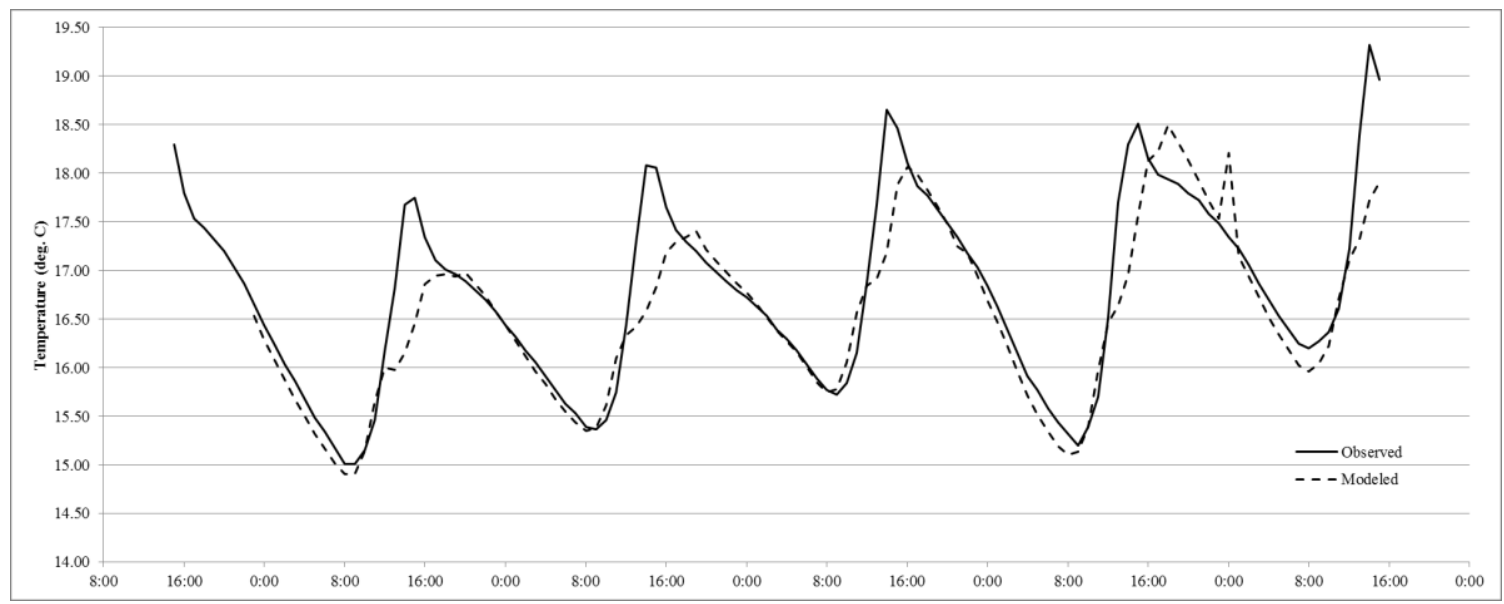

Figure 16. Observed and modeled stream temperatures on Scotts Creek at location $200 \mathrm{~m}$ from August 12-17, 2015.

Trends in heat budget variables and their relative heating or cooling influence on stream temperatures began to diverge from the net cooling trend observed over the first $50 \mathrm{~m}$ as a net warming effect occurred over the first $200 \mathrm{~m}$ (Figures 16, 17). Net radiation, latent heat exchange, and hyporheic flux were found to have statistically significant $(\alpha<.05)$ correlations with stream temperature change from 50-200 m (Table 15). Net radiation exhibited a net warming effect, likely due to decreases in stream shading between locations 50 and $200 \mathrm{~m}$ (Table 15).

Table 15. Regression analysis results, comparing heat budget components with hourly stream temperature change, on Scotts Creek over first $200 \mathrm{~m}$.

\begin{tabular}{|lccccc|}
\hline $\begin{array}{l}\text { Heat Budget } \\
\text { Variable }\end{array}$ & $\begin{array}{c}\text { Pearson } \\
\text { Correlation }\end{array}$ & $\beta$ & SE & $\mathrm{t}$ & $\mathrm{p}$ \\
\hline constant & - & -1.152 & 0.133 & -8.650 & 0.000 \\
$\mathrm{Nr}$ & 0.948 & 0.029 & 0.002 & 16.612 & 0.000 \\
$\mathrm{Qc}$ & 0.141 & - & - & - & - \\
$\mathrm{Qe}$ & 0.59 & 0.005 & 0.003 & 2.005 & 0.047 \\
Qh & 0.145 & 0.007 & 0.006 & 1.063 & 0.290 \\
Qhyp & 0.250 & 0.003 & 0.001 & 3.192 & 0.002 \\
\hline
\end{tabular}




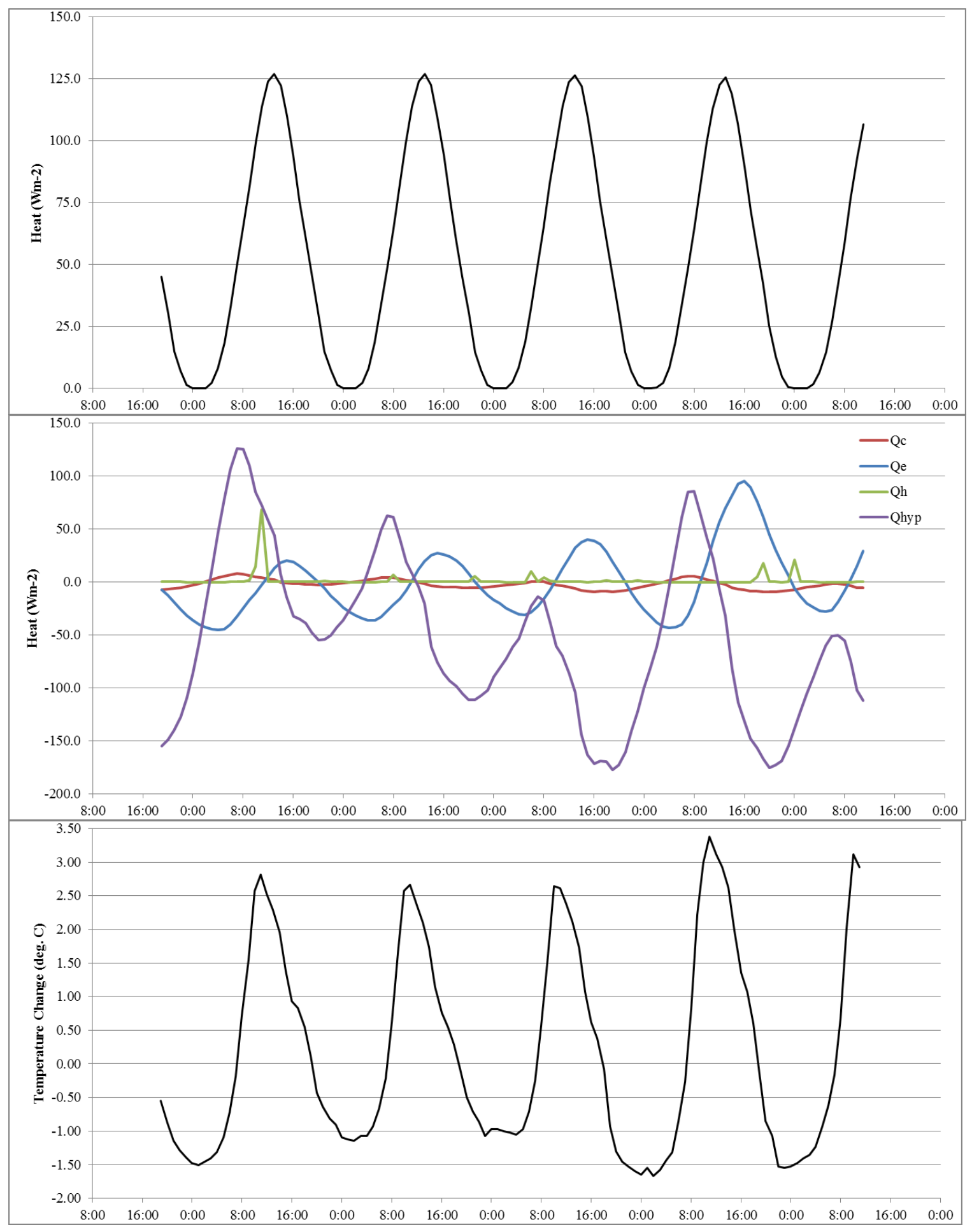

Figure 17. Plots of net radiation (top), heat budget components (middle), and hourly stream temperature change (bottom) on Scotts Creek at location $200 \mathrm{~m}$ from August 1217, 2015. 


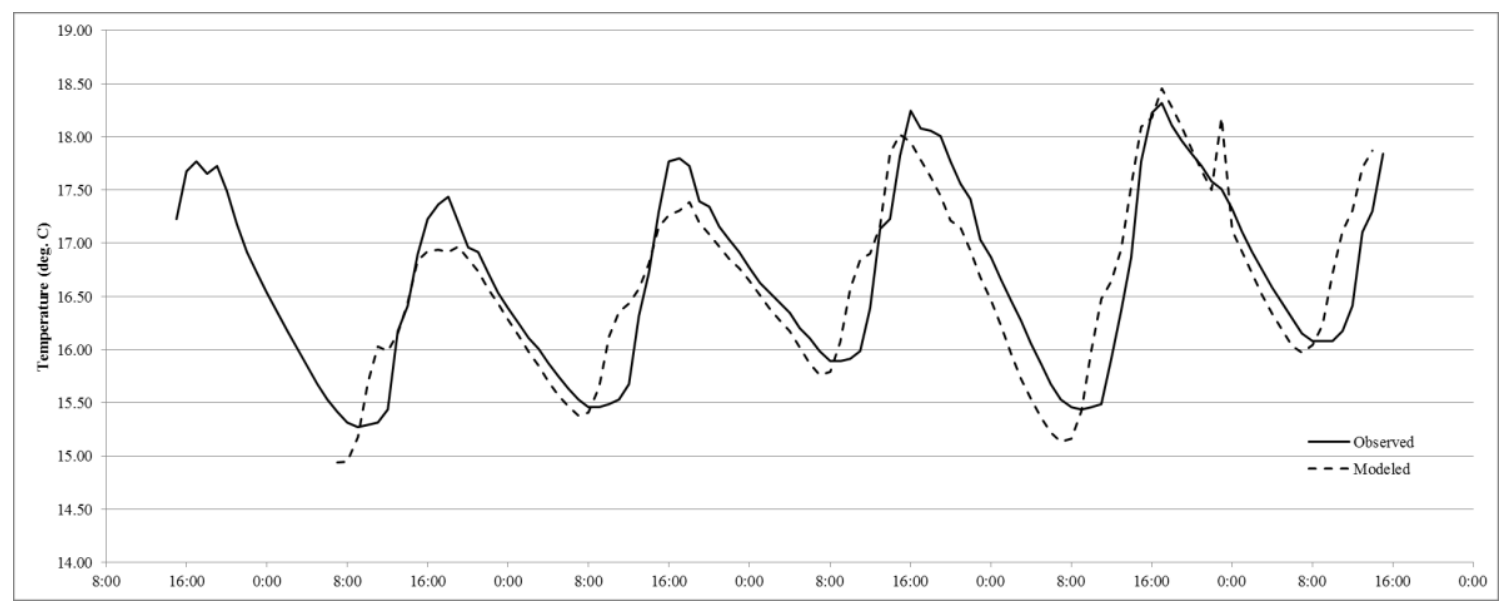

Figure 18. Observed and modeled stream temperatures on Scotts Creek at location $825 \mathrm{~m}$ from August 12-17, 2015.

A net cooling trend in temperatures occurred between locations 625 and $825 \mathrm{~m}$ with localized cooling and heating of differing magnitudes occurring between distance steps in the lower reach (Figures 18, 19). All variables, with the exception of sensible heat flux and hyporehic flux, were found to have a statically significant $(\alpha<.05)$ correlation with stream temperature change, with net radiation the most highly correlated (Table 16).

Table 16. Regression analysis results, comparing heat budget components with hourly stream temperature change, on Scotts Creek from locations 625 to $825 \mathrm{~m}$.

\begin{tabular}{|lccccc|}
\hline $\begin{array}{l}\text { Heat Budget } \\
\text { Variable }\end{array}$ & $\begin{array}{c}\text { Pearson } \\
\text { Correlation }\end{array}$ & $\beta$ & $\mathrm{SE}$ & $\mathrm{t}$ & $\mathrm{p}$ \\
\hline constant & - & -1.627 & 0.071 & -22.854 & 0.000 \\
$\mathrm{Nr}$ & 0.963 & 0.032 & 0.002 & 16.831 & 0.000 \\
$\mathrm{Qc}$ & 0.217 & 0.043 & 0.014 & 2.983 & 0.004 \\
Qe & 0.660 & 0.009 & 0.002 & 4.381 & 0.000 \\
Qh & -0.004 & -0.008 & 0.010 & -0.810 & 0.419 \\
Qhyp & 0.016 & - & - & - & - \\
\hline
\end{tabular}




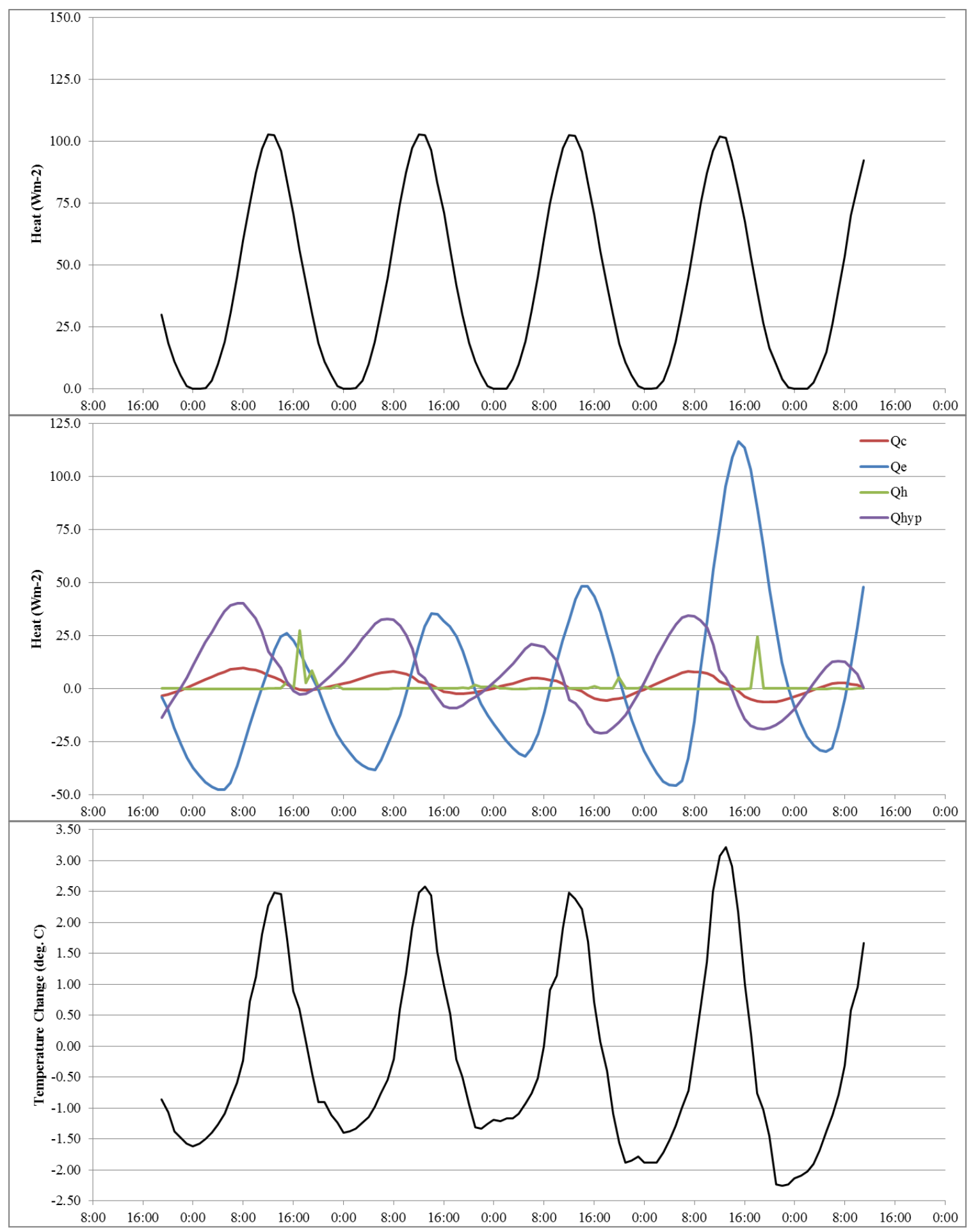

Figure 19. Plots of net radiation (top), heat budget components (middle), and hourly stream temperature change (bottom) on Scotts Creek at location $825 \mathrm{~m}$ from August 1217, 2015. 
Less hyporheic influence in the lower reach $(625-825 \mathrm{~m})$ is likely attributed to the lower measured hyporheic exchange rate compared to the upper reach possibly due to deviations in channel geometry and gradient which influence rates of downwelling. The dominant influence of net radiation throughout the lower reach, as well as the upper reach, is not only from localized reductions in stream shading from canopy gaps but from the slow movement of water and long stream residence times, potentially allowing heat to reside in the system for much longer compared to Little Creek. While long residence time of water at a given location has the potential to cause greater influence on daytime heating for that location, longer residence times conversely allow stream water to undergo nighttime cooling in a shorter distance as exhibited in daily temperature changes occurring over the lower reach (Figure 19).

\section{$\underline{\text { Physical Characteristics and Daily Maximum Temperatures }}$}

No measured physical characteristics were found to be statistically significant ( $\alpha$ $<.05)$ to daily maximum daily temperatures (Table 17).

Table 17. Regression analysis results, comparing physical channel variables and mean daily maximum stream temperature, on Scotts Creek.

\begin{tabular}{|lccccc|}
\hline Physical Variable & $\begin{array}{c}\text { Pearson } \\
\text { Correlation }\end{array}$ & $\beta$ & SE & $\mathrm{t}$ & $\rho$ \\
\hline constant & - & 17.358 & 4.855 & 3.576 & 0.005 \\
Width & 0.154 & -0.011 & 0.176 & -0.061 & 0.952 \\
Depth & -0.025 & -0.019 & 1.689 & -0.012 & 0.991 \\
Aspect ratio & 0.186 & 0.004 & 0.012 & 0.314 & 0.760 \\
Percent shading & -0.425 & -0.036 & 0.024 & -1.514 & 0.161 \\
Floodprone width & -0.141 & -0.151 & 0.252 & -0.6 & 0.562 \\
Bankfull width & 0.08 & 0.296 & 0.478 & 0.619 & 0.549 \\
Entrenchment ratio & -0.163 & 1.475 & 2.55 & 0.578 & 0.576 \\
\hline
\end{tabular}


Mostly weak correlations existed between all variables with a weak relationship between lower stream shading values and daily maximum temperatures ( $p$ value of 0.16 ). It is suspected that hydrologic processes observed for Scotts Creek, including relatively longer residence times and lower streamflow values, have effectively negated the influences of variables such as increased depth and aspect ratios which would normally be associated with cooler stream temperatures.

\section{Modeled Effects from Shade Reduction}

Modeled stream temperatures at locations $200 \mathrm{~m}$ and $825 \mathrm{~m}$ responded noticeably to both $50 \%$ and $100 \%$ shade reductions occurring over the first $200 \mathrm{~m}$ with the increased heat having less of an effect as water moves downstream (Table 18). Daily maximum temperatures at location $200 \mathrm{~m}$ increased by 2.27 and $3.30 \mathrm{deg}$. C for the $50 \%$ and $100 \%$ shade reduction scenarios respectively, while daily maximum temperatures at location $825 \mathrm{~m}$ increased by 1.84 and $3.11 \mathrm{deg}$. $\mathrm{C}$ for the $50 \%$ and $100 \%$ shade reduction scenarios respectively. Mean daily minimum temperatures were found to decrease under both shade reduction scenarios at both locations but only deviated by a maximum magnitude of $0.65 \mathrm{deg}$. C. Mean daily average temperatures were found to increase under both scenarios at both locations with only modest deviations of 0.49 deg. $\mathrm{C}$ or less. Results could not conclude what distance beyond $825 \mathrm{~m}$ would be affected by the additional heat, but do suggest that the additional upstream heat, coupled with localized cooling processes which naturally occur between various reaches, began to dissipate with increased distance downstream of the heat source. 
Table 18. Modeled results of shade reduction scenarios on Scotts Creek at locations 200 and $825 \mathrm{~m}$. Values for results at the distances and deviation from current are in deg. C.

\begin{tabular}{|ll|cc|cc|}
\hline $\begin{array}{l}\text { Mean Daily } \\
\text { Statistic }\end{array}$ & \multicolumn{1}{c}{ Shading scenario } & $200 \mathrm{~m}$ & $\begin{array}{c}\text { deviation } \\
\text { from current }\end{array}$ & $825 \mathrm{~m}$ & $\begin{array}{c}\text { deviation } \\
\text { from current }\end{array}$ \\
\hline \multirow{3}{*}{ Maximum } & Current & 18.25 & & 17.95 & \\
& $50 \%$ reduction & 20.52 & 2.27 & 19.79 & 1.84 \\
& $100 \%$ reduction & 21.55 & 3.30 & 21.06 & 3.11 \\
\hline \multirow{3}{*}{ Minimum } & Current & 15.32 & & 15.52 & \\
& $50 \%$ reduction & 15.24 & -0.08 & 15.43 & -0.09 \\
& $100 \%$ reduction & 14.67 & -0.65 & 15.39 & -0.13 \\
\hline \multirow{3}{*}{ Average } & Current & 16.71 & & 16.62 & \\
& $50 \%$ reduction & 17.17 & 0.46 & 17.10 & 0.48 \\
& $100 \%$ reduction & 17.19 & 0.48 & 17.11 & 0.49 \\
\hline
\end{tabular}

\section{Modeled Effects from Groundwater Inflows}

Modeled increases in groundwater inflows resulted in a net cooling effect of modeled temperatures at both $200 \mathrm{~m}$ and $825 \mathrm{~m}$ locations (Tables 19, 20). Deviations of mean daily maximum temperatures at location $200 \mathrm{~m}$ ranged from approximately -0.53 deg. C for a $10 \%$ increase and approximately $-1.93 \mathrm{deg}$. C for a $50 \%$ increase in groundwater inflow. Decreases in mean daily maximum temperatures at $825 \mathrm{~m}$ ranged from approximately $-0.27 \mathrm{deg}$. $\mathrm{C}$ to $-1.00 \mathrm{deg}$. $\mathrm{C}$ for $10 \%$ and $50 \%$ increases in groundwater inflow respectively. The magnitude of the net cooling effect increased at location $200 \mathrm{~m}$ from -1.93 to $-2.27 \mathrm{deg}$. C for the $50 \%$ to $100 \%$ shade reductions scenarios respectively while only a modest increase in magnitude occurred at location $825 \mathrm{~m}$ from $-1.00 \mathrm{deg}$. $\mathrm{C}$ to $-1.03 \mathrm{deg}$. C for the $50 \%$ and $100 \%$ shade reduction scenarios respectively. Modeled results indicate that potential groundwater increases from reduced evapotranspiration following near stream vegetation removal have the potential to partially mitigate the effects of additional heat added to the system. 
Table 19. Modeled results from groundwater inflows for $50 \%$ and $100 \%$ shade reduction scenarios on Scotts Creek at location $200 \mathrm{~m}$.

\begin{tabular}{|c|c|c|c|c|c|}
\hline $\begin{array}{l}\text { Mean Daily } \\
\text { Statistic }\end{array}$ & Groundwater scenario & $\begin{array}{c}50 \% \text { shade } \\
\text { reduction }\end{array}$ & $\begin{array}{c}\text { deviation from no } \\
\text { groundwater } \\
\text { inflow }\end{array}$ & $\begin{array}{c}100 \% \text { shade } \\
\text { reduction }\end{array}$ & $\begin{array}{c}\text { deviation from no } \\
\text { groundwater } \\
\text { inflow }\end{array}$ \\
\hline \multirow{4}{*}{ Maximum } & $10 \%$ increase & 19.99 & -0.53 & 20.93 & -0.62 \\
\hline & $20 \%$ increase & 19.55 & -0.97 & 20.41 & -1.14 \\
\hline & $30 \%$ increase & 19.18 & -1.34 & 19.98 & -1.57 \\
\hline & $50 \%$ increase & 18.59 & -1.93 & 19.28 & -2.27 \\
\hline \multirow{4}{*}{ Minimum } & $10 \%$ increase & 15.19 & -0.05 & 14.68 & 0.01 \\
\hline & $20 \%$ increase & 15.16 & -0.08 & 14.68 & 0.01 \\
\hline & $30 \%$ increase & 15.13 & -0.11 & 14.69 & 0.02 \\
\hline & $50 \%$ increase & 15.08 & -0.16 & 14.70 & 0.03 \\
\hline \multirow{4}{*}{ Average } & $10 \%$ increase & 16.95 & -0.22 & 16.97 & -0.22 \\
\hline & $20 \%$ increase & 16.77 & -0.40 & 16.79 & -0.40 \\
\hline & $30 \%$ increase & 16.62 & -0.55 & 16.63 & -0.56 \\
\hline & $50 \%$ increase & 16.37 & -0.80 & 16.38 & -0.81 \\
\hline
\end{tabular}

Table 20. Modeled results from groundwater inflows for $50 \%$ and $100 \%$ shade reduction scenarios on Scotts Creek at location $825 \mathrm{~m}$.

\begin{tabular}{|ll|cc|cc|}
\hline $\begin{array}{l}\text { Mean Daily } \\
\text { Statistic }\end{array}$ & \multicolumn{1}{c}{ Groundwater scenario } & $\begin{array}{c}50 \% \text { shade } \\
\text { reduction }\end{array}$ & $\begin{array}{c}\text { deviation from no } \\
\text { groundwater } \\
\text { inflow }\end{array}$ & $\begin{array}{c}\text { 100\% shade } \\
\text { reduction }\end{array}$ & $\begin{array}{c}\text { deviation from no } \\
\text { groundwater } \\
\text { inflow }\end{array}$ \\
\hline Maximum & $10 \%$ increase & 19.33 & -0.46 & 20.49 & -0.57 \\
& $20 \%$ increase & 18.95 & -0.84 & 20.01 & -1.05 \\
\hline & $30 \%$ increase & 18.62 & -1.17 & 19.61 & -1.45 \\
Minimum & $50 \%$ increase & 18.11 & -1.68 & 18.96 & -2.10 \\
& $10 \%$ increase & 15.37 & -0.06 & 15.33 & -0.06 \\
\hline \multirow{3}{*}{ Average } & $20 \%$ increase & 15.32 & -0.11 & 15.28 & -0.11 \\
& $30 \%$ increase & 15.27 & -0.16 & 15.24 & -0.15 \\
& $50 \%$ increase & 15.20 & -0.23 & 15.17 & -0.22 \\
\hline
\end{tabular}




\section{CHAPTER 6}

\section{DISCUSSION}

Observed stream temperature patterns for both the Little Creek and Scotts Creek study sites were found to be highly variable with respect to spatial distribution of daily maximum temperatures and with relative influences of individual heat budget variables. While results indicated a strong influence of net incoming radiation on daily temperatures, hydrologic characteristics of each study site were also influential. Hydrologic effects on stream temperature from hyporheic exchange and modeled groundwater inflows were important explanatory variables in the magnitude and spatial distribution of stream temperatures between two streams located in the same watershed subjected to similar meteorological conditions. The measurement and evaluation of a stream's hydrologic characteristics, stream shading, and aspect ratio, informs efforts to provide resource managers a methodology to predict stream temperature response to near stream vegetation removal.

\section{Stream Temperature Spatial Distribution}

Spatial distribution of maximum, minimum, and average daily temperatures were found to be highly variable for both Little Creek and Scotts Creek study sites with no discernible trend in the spatial distribution of reaches where localized heating and cooling occurred. Locations of localized temperature increases were associated with higher amounts of incoming radiation with localized cooling occurring where greater hyporheic exchange occurred. The spatial complexity is readily observable in the temperature 
measurements at both study sites and demonstrates the uncertainty with predicting the downstream transport and fate of added heat to streams.

Heat budget modeling provided the ability to evaluate temperature impacts with increasing distance downstream of a heat source and the relative contributions of individual heat budget components to localized heating and cooling mechanisms. Correlations between net radiation and physical channel measurements with stream temperature on Little Creek were found to be much weaker on Scotts Creek. The hydrologic characteristics of each stream system appears to be the difference. Scotts Creek had very low flow streamflow due to drought conditions creating longer water residence times. This low streamflow and long residence time influenced stream temperature magnitude and distribution.

\section{Hydrologic Processes and Influence}

Regression analysis indicated that hyporheic energy fluxes were negatively associated with increases in stream temperatures on Little Creek. Results from modelling of different shade reduction scenarios from hypothetical canopy removal indicated a decreased effect of added heat to the system as water moved downstream of the upstream heat source largely in part of subsurface-surface water interactions occurring at various locations through the study site as hypothesized. Observed hyporheic exchange rates and the prevalence of subsurface water mixing within both the North Fork and Main Stem Little Creek segments appears to be associated with channel morphological characteristics of the stream which include steeper channel gradients and the predominant 
step-pool and cascade configuration observed in the study site. The step-pool and cascade configuration of Little Creek promotes concentrated areas of downwelling and subsurface water mixing, particularly in riffles downstream of pools as indicated by the observed statistical relationship between higher aspect ratios and lower daily maximum temperatures. The spatial occurrences of these subsurface water interactions in Little Creek are consistent with previous research on streambed topography influences on surface-subsurface water interactions (Harvey and Bencala, 1993; Moore et al., 2005b; Burkholder et al., 2008). Departures from the steeper, step-pool configuration observed at Scotts Creek- with shallower channel gradients and more frequent occurrences of pools and glides compared to riffles- more than likely influenced the higher residence times of water and lower rates of hyphoreic exchange, particularly in the lower study reach. These attributes of the hydrologic regime of Scotts Creek, coupled with much lower surface flows compared to Little Creek, provide a rationale for the larger modeled increases in maximum stream temperatures compared to Little Creek.

Modeled increases of daily maximum stream temperatures for both the $50 \%$ and $100 \%$ shade reduction scenarios in the upper $300 \mathrm{~m}$ of the Little Creek study site resulted in modest increases of 1.76 and $2.16 \mathrm{deg}$. $\mathrm{C}$ respectively. Other studies on maximum stream temperature increase due to forest clearing found much higher increases. compared to an approximately $5 \mathrm{deg}$. $\mathrm{C}$ increase in daily maximum temperatures observed in a study by Moore et al. (2005b) evaluated downstream temperature response to clear-cut harvesting in a forested headwater stream in coastal British Columbia found a 5 deg. C increase. Heat budget modelling in the Moore et al. (2005b) study did indicate that hyporheic exchange promoted localized daytime cooling effects, similar to Little 
Creek. Discrepancies in maximum temperature increases following canopy removal compared to Moore's study can possibly be explained by greater areas of concentrated downwelling in Little Creek. In a headwater stream in the western Cascades of Oregon following timber harvest maximum stream temperature increased by $7 \mathrm{deg}$. C (Johnson and Jones, 2000). Streambed conduction from a bedrock channel was reported to be an influential factor in this large stream temperature increase. The bedrock channel bed would have had little to no hyporheic exchange. Warmer observed daily maximum temperatures and larger modeled increases following canopy removal ( $\sim 3 \mathrm{deg} . \mathrm{C})$ on Scotts Creek compared to Little Creek can possibly be attributed to greater influence by streambed conduction and lower rates of subsurface-surface water interactions. Higher observed maximum streambed temperatures on Scotts Creek along with a greater range in streambed conduction fluxes $\left(-29.3\right.$ to $\left.15.5 \mathrm{Wm}^{-2}\right)$ may indicate a more frequent occurrence of downwelling and less upwelling of cooler water within the study site compared to lower observed maximum streambed temperatures and lower fluctuations in daily streambed conduction fluxes $\left(-1.5\right.$ to $22.7 \mathrm{Wm}^{-2}$ ) observed on Little Creek as suggested by findings by Moore et al. (2005b). These inferences however cannot be fully substantiated by the heat budget modeling approach taken for this study as streambed hydraulic conductivity and streambed composition were not measured.

While groundwater inflows were found to be negligible, and not a measured element of the two study sites, the potential for increases in groundwater inflows following near stream vegetation removal can be significant (e.g. Mellina et al., 2002; Surfleet and Skaugset, 2013; Story et al., 2013). The cooling effect from groundwater convection on stream temperatures provided the importance of modelling stream 
temperature responses to potential groundwater increases following canopy removal for both Little Creek and Scotts Creek. Modeled increases in groundwater inflows, as expressed by increases in overall surface water flow, dampened the effect of stream temperature increases from canopy removal with $50 \%$ increases in streamflow under the $100 \%$ shade reduction scenario causing temperature increases (e.g. mean daily max. of 19.28 deg. C for Scotts Creek at location $200 \mathrm{~m}$ ) to be less than that of temperature increases from the $50 \%$ shade reduction scenario with no groundwater inflow (e.g. mean daily max. of 21.55 deg. C for Scotts Creek at location $200 \mathrm{~m}$ ). Observations of stream temperature and streamflow responses following potential canopy removal in either of the two study sites will be necessary to better evaluate the potential cooling effects of groundwater inflows, but modelling of different magnitudes of groundwater inflows provides some useful insight into potential downstream temperature effects at both study sites.

\section{Proposed Methodologies for Predicting Downstream Effects}

Results from this study demonstrate a potential approach to spatially identify localized areas of heating and cooling and to be able to model the risk of potential downstream cumulative temperature effects. Measurements of stream temperature along with the collection of meteorological, channel morphological, and hydrologic data were beneficial in the development of a heat budget model that predicted daily maximum temperatures within $0.55 \mathrm{deg}$. $\mathrm{C}$ for both study sites. Dye tracer methods proved to be particularly important in obtaining precise low flow measurements and modeling for hyporheic exchange, average stream residence time, and the assessment of heat fate and 
transport. Accurate depictions of the hydrologic characteristics of a stream system can potentially provide resource managers with a better understanding of the potential localized and downstream effects from forest harvest. Methods used in this study for obtaining this hydrologic information, however, is likely not a viable approach for most resource managers and regulators due to time and monetary constraints. Collection of high-resolution spatial stream temperature data along with meteorological data and subsequent heat budget modeling are also not likely to be feasible options compared to more simplified methodologies of statistically relating physical channel variables or canopy cover to the spatial distribution of maximum stream temperatures.

Simple physical channel measurements of stream shading and aspect ratio proved to be a statistically relevant $(\alpha<.05)$ means of predicting the spatial distribution of mean daily maximum temperatures for the Little Creek study site. Summer low flow conditions, where annual maximum stream temperatures are highest, have the most potential to exceed regulatory or management thresholds following forest harvest or other landscape disturbance such as wildfire. These variables however were not found to be statistically relevant $(\alpha<.05)$ for the Scotts Creek study site and demonstrate the inherent complexity of stream temperature dynamics among two streams within the same watershed and the challenge in the development of a more practical, repeatable approach to predict potential downstream temperature impacts.

More detailed and repeated measurements of physical channel variables and statistical analyses in their predictive power, beyond the approach taken in this study, are needed to draw better conclusions about the development of a more simplified and 
accurate methodology for predicting downstream effects. Measurements of streambed topography including slope, slope change, channel geometry, and streambed composition could potentially provide more predictive power in identifying localized areas of hyporheic exchange, downwelling, or upwelling. A survey of channel morphological features, including the frequency and size of pools and riffles, could also allow for better inferences of surface-subsurface water exchanges for a stream.

Challenges in developing universally applicable methods that use simple physical channel variables, along with other easier-to-obtain data such as air temperature, are more than likely linked to varying hydrologic conditions among stream systems. Measurement and prediction of hyporheic exchange and groundwater flow are often limited by time and budget restraints for most resource managers. Further investigation into the potential relation of simple physical channel measurements with location and occurrence of hyporheic exchange could help offset the effort required to predict hyporheic exchange. Streamflow measurements made periodically downstream through a study reach of interest would also be an efficient way of determining net flow gains and losses from groundwater. Results from this study demonstrated that measured groundwater temperature and potential groundwater inflows, along with measured hyporheic exchange and hyporheic temperatures, were beneficial in assessing potential buffer effects to stream temperatures. Canopy cover, as a surrogate for net radiation, and aspect ratio were also beneficial measurements in predicting the spatial distribution of daily maximum temperatures in some streams. Hydrologic measurements are likely needed in conjunction with other physical or meteorological measurements to better assess potential sitespecific impacts. 


\section{CHAPTER 7}

\section{CONCLUSIONS}

Data collection methods and heat budget modeling provided meaningful insight into the thermal dynamics of Little Creek and Scotts Creek and their potential temperature response to upstream forest harvest or disturbance resulting in canopy and stream shading reduction. Stream temperatures, particularly mean daily maximum temperatures, were found to vary spatially (ranging from 14.95 to $17.91 \mathrm{deg}$. C on Little Creek and 16.52 to $18.67 \mathrm{deg}$. C on Scotts Creek) due to a variety of observed and measured cooling and heating mechanisms occurring throughout both study sites. Daily maximum, minimum, and average temperatures were found to be warmer for Scotts Creek (average daily maximum of 17.34 deg. C) compared to Little Creek (average daily maximum of $15.46 \mathrm{deg}$. C) likely due to differences in measured and modeled hydrologic conditions between the two sites and position in the stream network. Scotts Creek has greater watershed area above it with potentially greater heat accumulation than Little Creek.

Statistical analyses of individual heat budget component contributions to stream heating and cooling indicated that the magnitude and spatial frequency of subsurfacesurface water interactions, along with incoming net radiation, were the most significant variables in both Little Creek and Scotts Creek. The influence of net radiation and hyporheic exchange however varied within both study sites. While hyporheic exchange was found to be highly significant $(p=0.000)$ over all distances which temperature change was observed on Little Creek, net radiation became more significant with 
increased downstream distance ( $p=0.277$ to 0.067 to 0.000 over the first 100,300 , and $800 \mathrm{~m}$ respectively). Net radiation $(\mathrm{p}=0.000)$ was highly significant over all distances in Scotts Creek while hyporheic exchange $(p=0.002)$ was significant for only the upper reach. Spatial discrepancies in hyporheic influence on stream temperatures in Scotts Creek were attributed to the lower hyporheic exchange rates and much longer average residence time in the lower reach ( $\sim 17.6$ days) compared to the upper reach ( $\sim 2.5$ days). Cooler stream temperatures measured on Little Creek and the greater dissipation of heat is likely attributed to the higher measured streamflow and lower average residence times ( $\sim 0.99$ hrs.). Inherent assumptions made in hydrologic modeling, including the potential presence of lateral subsurface inflow and other transient storage factors, creates uncertainty in hyporheic exchange rate estimates, but serve as a useful metric in computing and evaluating the relative influence of hyporheic fluxes on stream temperatures relative to other heat budget variables.

Accurate or representative depictions of hyporheic and groundwater fluxes are particularly important in systems like Little Creek with channel morphological characteristics that promote more subsurface-surface water interactions. Stream aspect ratio was a highly significant predictor $(p=0.001)$ of daily maximum temperatures in Little Creek but not on Scotts Creek $(p=0.760)$. The difference in the significance of aspect ratio is likely linked to the hydrologic characteristics of the two creeks including rates of concentrated upwelling and downwelling. More detailed analyses of physical channel characteristics, coupled with hydrologic measurements made at higher spatial resolutions, could provide more insight into the predictive power of physical channel measurements on stream temperatures. 
The development of a comprehensive heat budget model provided pertinent predictions in downstream temperature response to potential upstream forest harvest. Modeling results from stream shade reductions indicated daily maximum temperature increases of 2.16 deg. C in Little Creek and 3.30 deg. C in Scotts Creek immediately downstream of the hypothetical harvested reaches and indicated decreased impacts with increased downstream distance of the harvested reaches (1.62 and 3.11 deg. C for Little Creek and Scotts Creek respectively). Daily average and minimum temperatures only deviated by a maximum of $+/-0.65 \mathrm{deg}$. $\mathrm{C}$ for both study sites. Modeled results from potential increases in groundwater inflows following hypothetical canopy reduction scenarios, where groundwater inflow was negligible or nonexistent under current conditions, reduced daily maximum temperatures by upwards of $2.27 \mathrm{deg}$. C in Scotts Creek and $1.03 \mathrm{deg}$. C in Little Creek from daily maximum temperatures modeled under the $100 \%$ shade reduction scenario.

Hydrologic characteristics of Little Creek and Scotts Creek were significant variables in the magnitude and distribution of stream temperatures and helped explain the spatial variability of daily maximum temperatures between and within study sites. Temperature observations and modeling over longer time periods would provide more insight into persistence and potential recovery of stream temperature impacts following forest harvest. Observations of stream temperatures following forest harvest, ecological restoration, or other landscape disturbance would also be necessary to confirm or potentially validate modeling results from this study. Nevertheless, predicted stream temperature responses to near stream canopy reductions from this study provides pertinent information to land managers and policy-decision makers in the assessment of 
potential impacts and development of adaptive management strategies for Little Creek and Scotts Creek. 


\section{REFERENCES}

Anderson, R. S. "Evolution of Santa Cruz Mountains, California, through tectonic growth and geomorphic decay." Journal of Geophysical Research 99.B10 (1994): 20,161-20,179. Print.

Anderson, Paul D., David J. Larson, and Samuel S. Chan. "Riparian Buffer and Density Management Influences on Microclimate of Young Headwater Forests of Western Oregon." Forest Science 53.2 (2007): 254-69. Print.

Andreassian, V. "Waters and forests: from historical controversy to scientific debate." Journal of Hydrology 291 (2004): 1-27. Print.

Bell, M.C.. "Fisheries handbook of engineering requirements and biological criteria." Fish Passage Development and Evaluation Program. U.S. Army Corps of Engineers (1986): 209. Print.

Beschta, R.L.; Bilby, R.E.; Brown, G.W.; Holtby, L.B.; Hofstra, T.D. "Stream temperature and aquatic habitat: fisheries and forestry interactions." Streamside management: forestry and fishery interactions. Contribution No. 57 (1987): 191232. Print.

Beschta, Robert L., and R. Lynn Taylor. "Stream Temperature Increases and Land Use in a Forested Oregon Watershed1." JAWRA Journal of the American Water Resources Association 24.1 (1988): 19-25. Print.

Boughton, David A., Christine Hatch, and Ethan Mora. "Identifying Distinct Thermal Components of a Creek." Water Resources Research 48.9 (2012): W09506. Print.

Bowman, R., and Estrada, D. "Soil survey of Santa Cruz County, California." USDA National Resource Conservation Service (NRCS) report. NRCS, 1976. Web. 15. Jan. 2014.

Briggs, Martin A., Laura K. Lautz, and Jeffrey M. McKenzie. "A Comparison of Fibre-Optic Distributed Temperature Sensing to Traditional Methods of Evaluating Groundwater Inflow to Streams." Hydrological Processes 26.9 (2012): 1277-90. Print.

Brosofske, Kimberley D., et al. "Harvesting Effects on Microclimatic Gradients from Small Streams to Uplands in Western Washington." Ecological Applications 7.4 (1997): 1188-200. Print. 
Brown, G.W. "Water temperature in small streams as influenced by environmental factors and logging." Forest land uses and stream environment (1971): 175-181. Print.

Brown, George W., and James T. Krygier. "Effects of Clear-Cutting on Stream Temperature." Water Resources Research 6.4 (1970): 1133-39. Print.

Burkholder et al. "Influence of Hyporheic Flow and Geomorphology on Temperature of a Large, Gravel-Bed River, Clackamas River, Oregon, USA.” Hydrological Processes 22.7 (2008): 941-953. Print.

California Department of Forestry and Fire Protection (CDF). "2014 Forest Practice Rules and Act". Resource Management: Forest Practice. CDF. 2014. Web. 16. Jan. 2014.

California Department of Forestry and Fire Protection (CDF). "Anadromous Salmonid Protection Rule Section V". Site-Specific Riparian Management: Section V Guidance. Sacramento, CA, 2012. CDF, Sacramento, CA, 2013. Print.

California Irrigation Management Information System (CIMIS). Station: De Laveaga. CIMIS 2015. Web. 15. June. 2016.

California State Water Resources Control Board (SWRCB). "2002 Clean Water Act Section 303(d) List of Water Quality Limited Segments. " Water Issues. 2002. Web. 25 Jan. 2013.

Cole, Elizabeth and Michael Newton. "Influence of Streamside Buffers on Stream Temperature Response Following Clear-Cut Harvesting in Western Oregon". Canadian Journal of Forestry Research 43.11 (2013): 993-1005. Print.

Constantz, Jim. "Interaction between Stream Temperature, Streamflow, and Groundwater Exchanges in Alpine Streams." Water Resources Research 34.7 (1998): 1609-15. Print.

DeWalle, David R. "Modeling Stream Shade: Riparian Buffer Height and Density as Important as Buffer Width1." JAWRA Journal of the American Water Resources Association 46.2 (2010): 323-33. Print.

Donaldson, J.R., and Tryon, P.V. “User's guide to STARPAC-The standards, time series, and regression package: National Institute of Standards and Technology Internal Report" NBSIR (1990): 86-3448. Print

Evans, E. C., G. R. McGregor, and G. E. Petts. "River Energy Budgets with Special Reference to River Bed Processes." Hydrological Processes 12.4 (1998): 575-95. Print. 
Feller MC. "Effects of clearcutting and slashburning on stream temperature in southwestern British Columbia". Water Resources Bulletin 17 (1981): 863-867. Print.

Gaedeke, M.C. "Preharvest calibration of the Little Creek watershed: a paired and nested watershed analysis." California Polytechnic State University, San Luis Obispo. MS Thesis (2006): 116. Print.

Gomi, Takashi, R. Dan Moore, and Amod S. Dhakal. "Headwater Stream Temperature Response to Clear-Cut Harvesting with Different Riparian Treatments, Coastal British Columbia, Canada." Water Resources Research 42.8 (2006): W08437. Print.

Harper, K. A., and S. E. Macdonald. "Structure and composition of edges next to $r$ egenerating clearcuts in the mixed wood boreal forest." Journal of Vegetation Science 13 (2002): 535-546. Print.

Harris DD. 1977. "Hydrologic changes after logging in two small Oregon coastal watersheds." Geological Survey Water-Supply Paper 2037 (1977): 31. Print.

Harvey, Judson W., and Kenneth E. Bencala. "The Effect of Streambed Topography on Surface-Subsurface Water Exchange in Mountain Catchments." Water Resources Research 29.1 (1993): 89-98. Print.

Harvey, J.W., Wagner, B.J., and Bencala, K.E. "Evaluating the reliability of the stream tracer approach to characterize stream-subsurface exchange". Water Resources Research 32.8 (1996): 2441-2451. Print.

Hausner et al. "Calibrating Single-Ended Fiber-Optic Raman Spectra Distributed Temperature Sensing Data." Sensors 11.11 (2011): 10859-10879. Print.

Hewlett, J.D. and J.C. Fortson. "Stream Temperature Under an Inadequate Buffer Strip in the Southeast Piedmont." Water Resources Bulletin 18 (1982): 983-988. Print.

Ice, George G., Jeff Light, and Maryanne Reiter. "Use of Natural Temperature Patterns to Identify Achievable Stream Temperature Criteria for Forest Streams." Western Journal of Applied Forestry 19.4 (2004): 252-59. Print.

Janisch, Jack E., Steven M. Wondzell, and William J. Ehinger. "Headwater Stream Temperature: Interpreting Response after Logging, with and without Riparian Buffers, Washington, USA." Forest Ecology and Management 270.0 (2012): 30213. Print.

Johnson, Sherri L. "Stream Temperature: Scaling of Observations and Issues for Modelling." Hydrological Processes 17.2 (2003): 497-99. Print. 
Johnson, Sherri L., and Julia A. Jones. "Stream Temperature Responses to Forest Harvest and Debris Flows in Western Cascades, Oregon." Canadian Journal of Fisheries and Aquatic Sciences 57.S2 (2000): 30-39. Print.

Johnson, S.L. "Factors influencing stream temperatures in small streams: substrate effects and a shading experiment." Canadian Journal of Fisheries and Aquatic Sciences 61 (2011): 913-923. Print.

Keppeler, E.T., and R.R. Ziemer. "Logging effects on streamflow: water yield and summer low flows at Caspar Creek in northwestern California." Water Resources Research 26.7 (1990): 1669 -1679. Print.

Kilpatrick, F.A., and E.D. Cobb. 1985. "Measurement of Discharge using Tracers.” United States Geological Survey. 1985. Web. 12. May. 2014.

Kreutzweiser, David P., Scott S. Capell, and Stephen B. Holmes. "Stream Temperature Responses to Partial-Harvest Logging in Riparian Buffers of Boreal Mixedwood Forest Watersheds." Canadian Journal of Forest Research 39.3 (2009): 497-506. Print.

Laenen, Antonius, and Kenneth E. Bencala. "Transient Storage Assessments of DyeTracer Injections in Rivers of the Willamette Basin, Oregon1." JAWRA Journal of the American Water Resources Association 37.2 (2001): 367-77. Print.

Lowry, Christopher S., et al. "Identifying Spatial Variability of Groundwater Discharge in a Wetland Stream Using a Distributed Temperature Sensor." Water Resources Research 43.10 (2007): W10408. Print.

Macdonald, J. S., E. A. MacIsaac, and H. E. Herunter. "The Effect of Variable-Retention Riparian Buffer Zones on Water Temperatures in Small Headwater Streams in Sub-Boreal Forest Ecosystems of British Columbia." Canadian Journal of Forest Research 33.8 (2003): 1371-82. Print.

Mamer, Ethan A., and Christopher S. Lowry. "Locating and Quantifying Spatially Distributed Groundwater/Surface Water Interactions Using Temperature Signals with Paired Fiber-Optic Cables." Water Resources Research 49.11 (2013): 767080. Print.

McCullough, D. A., et al. "Summary of technical literature examining the physiological effects of temperature on salmonids." Region 10 temperature water quality criteria guidance development project. U.S. Environmental Protection Agency (2001): EPA-910-D-01-005. Print. 
Mellina, Eric, et al. "Stream Temperature Responses to Clearcut Logging in British Columbia: The Moderating Influences of Groundwater and Headwater Lakes." Canadian Journal of Fisheries and Aquatic Sciences 59.12 (2002): 1886-900. Print.

Montgomery, David R., and John M. Buffington. "Channel-Reach Morphology in Mountain Drainage Basins." Geological Society of America Bulletin 109.5 (1997): 596-611. Print.

Moore, R.D., D.L. Spittlehouse, and A. Story. "Riparian microclimate and stream temperature response to forest harvesting: a review. "Journal of the American Water Resources Association Aug. (2005a): 814-834. Print

Moore, R. D., et al. "Thermal Regime of a Headwater Stream within a Clear-Cut, Coastal British Columbia, Canada." Hydrological Processes 19.13 (2005b): 2591-608. Print.

National Oceanic Atmospheric Administration (NOAA). "Central California coast coho salmon recovery plan." North Central Coast Steelhead and Salmon Recovery Plans. 2012. Web. 18 Jan. 2013.

Perkins, Drew A. "Evaluating Geomorphic Change In Little Creek Using Repeated Cross-Sectional and Longitudinal Profile Surveys." California Polytechnic State University, San Luis Obispo. MS Thesis (2012). Print.

Piirto, D.D. et al. "Implementing uneven-aged redwood management at Cal Poly's school forest, an update." Swanton Pacific Ranch: Documents. California Polytechnic State University, San Luis Obispo. 1999. Web. 30. Mar. 2014.

Pollock, Michael M., et al. "Stream Temperature Relationships to Forest Harvest in Western Washington1." JAWRA Journal of the American Water Resources Association 45.1 (2009): 141-56. Print.

Poole, Geoffrey C., and Cara H. Berman. "An Ecological Perspective on in-Stream Temperature: Natural Heat Dynamics and Mechanisms of Human-Causedthermal Degradation." Environmental Management 27.6 (2001): 787-802. Print.

Rishel, Gregg B., James A. Lynch, and Edward S. Corbett. "Seasonal Stream Temperature Changes Following Forest Harvesting." J. Environ. Qual. 11.1 (1982): 112-16. Print.

Ronan, Anne Dudek, et al. "Field Study and Simulation of Diurnal Temperature Effects on Infiltration and Variably Saturated Flow beneath an Ephemeral Stream." Water Resources Research 34.9 (1998): 2137-53. Print. 
Runkel, R.L. "One-dimensional transport with inflow and storage (OTIS): a solute transport model for streams and rivers." U.S. Geological Survey Water Resources Investigations Report. (1998): 98-4018. 80. Print.

Runkel, R.L., and Broshears, R.E. "One-dimensional transport with inflow and storage (OTIS) - A solute transport model for small streams." University of Colorado, CADSWES Technical Report 91.01 (1991): 85. Print.

Rothatcher, J. 1970. "Increases in water yield following clearcut logging in the Pacific Northwest." Water Resources Research 6.2 (1970): 653- 658. Print.

Rutherford, J. C., et al. "Effects of Patchy Shade on Stream Water Temperature: How Quickly Do Small Streams Heat and Cool?" Marine and Freshwater Research 55.8 (2004): 737-48. Print.

Story, A., R. D. Moore, and J. S. Macdonald. "Stream Temperatures in Two Shaded Reaches Below Cutblocks and Logging Roads: Downstream Cooling Linked to Subsurface Hydrology." Canadian Journal of Forest Research 33.8 (2003): 138396. Print.

Sullivan K, Adams TA. "The physics of stream heating: an analysis of temperature patterns in stream environments based on physical principles and field data." Weyerheauser Technical Report. 044 - 5002·90/2 (1990). Print.

Surfleet, Christopher G., and Arne E. Skaugset. "The Effect of Timber Harvest on Summer Low Flows, Hinkle Creek, Oregon." Western Journal of Applied Forestry 28.1 (2013): 13-21. Print.

Swift, W.L. and J.B. Messer. "Forest Cuttings Raise Temperatures of Small Streams in Southern Appalachians.” Journal of Soil and Water Conservation 26.3 (1971): 111-116. Print.

Tyler, Scott W., et al. "Environmental Temperature Sensing Using Raman Spectra DTS Fiber-Optic Methods." Water Resources Research 45.4 (2009): W00D23. Print.

Washington State Department of Ecology (WDOE). "Evaluating Standards for Protecting Aquatic Life in Washington's Surface Water Quality Standards: Temperature Criteria.” WDOE 00-10-070 (2002): 189. Print.

Webb, Bruce W., et al. "Recent Advances in Stream and River Temperature Research." Hydrological Processes 22.7 (2008): 902-18. Print.

Webb, B.W. and Y. Zhang. "Spatial and temporal variability in the components of the river heat budget." Hydrological Processes 11 (1997): 79-101. Print. 
Welsh, Hartwell H., et al. "Distribution of Juvenile Coho Salmon in Relation to Water Temperatures in Tributaries of the Mattole River, California." North American Journal of Fisheries Management 21.3 (2001): 464-470. Print.

Wurtsbaugh, W. A., and G. E. Davis. "Effects of temperature and ration level on the growth and food conversion efficiency of Salmo gairdneri". Journal of Fish Biology 11 (1997): 87-98. Print. 